\title{
A Critical Evaluation of Single Extractions from the SMT Program to Determine Trace Element Mobility in Sediments
}

\author{
Valérie Cappuyns ${ }^{1,2}$ \\ ${ }^{1}$ Center for Economics and Corporate Sustainability (CEDON), University College Brussels (HUB), Warmoesberg 26, \\ 1000 Brussels, Belgium \\ ${ }^{2}$ Department of Earth and Environmental Sciences, KULeuven, Celestijnenlaan 200E, 3001 Heverlee, Belgium
}

Correspondence should be addressed to Valérie Cappuyns, valerie.cappuyns@hubrussel.be

Received 30 November 2011; Revised 27 March 2012; Accepted 4 April 2012

Academic Editor: Larissa Macedo dos Santos

Copyright ( 2012 Valérie Cappuyns. This is an open access article distributed under the Creative Commons Attribution License, which permits unrestricted use, distribution, and reproduction in any medium, provided the original work is properly cited.

\begin{abstract}
Two commonly applied single extractions procedures, namely extractions with ammonium-EDTA and acetic acid, were evaluated based on the analysis of 72 samples from alluvial sediments. For most trace elements $(\mathrm{Cu}, \mathrm{Zn}, \mathrm{Cd}, \mathrm{Ni}, \mathrm{As}$, and $\mathrm{Pb})$, a significant linear relationship could be established between their ammonium-EDTA or acetic acid extractable concentrations and their total concentrations, the organic carbon content, $\mathrm{pH}$, and $\mathrm{Fe}, \mathrm{Al}$, and/or $\mathrm{Ca}$ content in the sediments. The scientific understanding of trace element partitioning in the complex soil-water system with these simple models is rather limited, but they offer the opportunity to use data from single extractions in a more comprehensive way. Despite the fact that these extractions cannot directly be related to the bioavailability of elements, they can provide input data for use in risk assessment models. Additionally, they also offer possibilities to perform a fast screening of the mobilizable pool of elements in soils and/or sediments.
\end{abstract}

\section{Introduction}

The contamination of soils and sediments is widespread and is a potential threat for the environment in the short and long term. The impact of trace elements in soils and sediments on the environment depends on their speciation, mobility, and bioavailability. Over the past decades, the term "heavy metals" has increasingly been used, without any consistency to denote trace element contamination of environmental media. An overview of the use of the term "heavy metals" in scientific dictionaries and relevant literature can be found in Duffus [1]. Since "heavy metals" is a poor scientific term and many alternatives exit [2], we will use the term "trace elements" in the present study to refer to $\mathrm{As}, \mathrm{Cd}, \mathrm{Cu}, \mathrm{Cr}, \mathrm{Ni}$, $\mathrm{Pb}$, and $\mathrm{Zn}$. Talking about trace metals would be incorrect because arsenic is actually a metalloid.

Before discussing the different methods for determination of "trace element" availability in soils and/or sediments and before addressing the pros and cons of single and sequential extraction procedures, the difference between soils and sediments will be clarified, as well as the terminology used throughout this paper.
1.1. Soils versus Sediments. Soils and sediments are different matrixes from many viewpoints, especially under the environmental context. "Soil" can be defined as a "threedimensional body with properties that reflect the impact of climate, vegetation, fauna, and topography on soils parent material over a variable time span. Soils are still in a process of change. As a result of "soil formation" or "pedogenesis," soil profiles show signs of differentiation or alteration of the soil material [3]." "Sediment" can be described as "material that is transported by water and settles down from the water column [4]. In freshly deposited alluvial sediments, signs of differentiation or alteration of the material are sometimes not yet observable." Nevertheless, in soil classification, specific designations are foreseen for this kind of "material": alluvial soils can often be classified as Fluvisols, which "exhibit a stratified profile that reflects their depositional history or an irregular layering of humus and mineral sediments in which the content of organic carbon decreases with depth [5]." The qualifiers fluvic and spolic are used to indicate, respectively, the regular deposition of fresh sediments or the deposition of dredged sediments on a soil. 
Throughout this paper, the term "sediment" will be used to indicate both the river sediments and the alluvial soils that consist of dredged-sediment derived soils and overbank sediments, regardless of their specific origin (e.g., overbank flooding, dredged-sediment derived soils, etc.), the degree of alteration, or the catchment width.

1.2. Trace Element Mobility in Soils and Sediments: Experimental Approach. "Trace element mobility" is an operationally defined term, which is determined by an approach used to determine the mobile, labile, or available metal species in soils and sediments. Although spectroscopic tools such as X-ray adsorption fine structure (XAFS) spectroscopy can give information on the coordination chemistry of metals (e.g., [6]), the quantification of the most mobile species is still difficult.

The composition of soil pore water is important from an environmental point of view because it gives an indication of the "actual mobility" of trace elements and because the uptake of trace elements by plants occurs via the pore water. Moreover, pore water is also the carrier for elements to the groundwater. Leaching is the process by which inorganic or organic contaminants in the pore water are moved to deeper soil layers or to the groundwater by infiltrating water. However, the pore water composition only gives a momentary picture of trace element mobility since pore water composition can change over time. To assess trace element mobility in the long term (referred to as "potential mobility," including physicochemically and biologically available metal pools) and under changing environmental conditions a variety of leaching and extractions tests are used. According to Peijnenburg et al. [7], three approaches can be distinguished to quantify physicochemically and biologically available metal pools in the soil: (1) direct measurement or modelling of metal activities, (2) assessment of operationally defined element fractions by means of single and sequential extractions, and (3) application of semipermeable devices, such as ion exchange resins/membranes and toxicity tests with membrane devices. For example, the in situ technique of diffusive gradients in thin films (DGT) is used for measuring effective soil solution concentrations and the additional element concentration supplied from the solid phase.

The direct measurement of metal activities in pore water is rather complex, and there is not always an agreement between measured and model concentrations of free metal ion activities [8]. Several investigations have also been performed to compare the results of diffuse gradients in thin films (DGT) with single and sequential extraction methods. Roulier et al. [9] compared the mobilisation of $\mathrm{Co}, \mathrm{Cd}$, and $\mathrm{Pb}$ in sediments using DGT and sequential extractions and found a correlation between the masses of metals trapped in DGT resins and the metals extracted during sequential extractions. Other authors concluded that the DGTmethodology did not have an additional value in predicting bioavailability of zinc [10] or uranium [11] in terrestrial ecosystems as compared to conventional extraction methods. Nevertheless, the DGT measure of trace elements provides a promising indicator of their toxicity [12], but interacting effects should first be clarified before DGT can be used in routinely risk assessment of soils and sediments.

The present work will focus on the second approach, with emphasis on two commonly applied single extractions procedures, which will be critically evaluated.

1.3. Single and Sequential Extractions. Single and sequential extractions provide semiquantitative information on element distribution between operationally defined geochemical fractions. Therefore, the fractions obtained from single and sequential extraction do not necessarily reflect true chemical speciation. The different extractions are often intended to simulate processes in nature, such as acidification or oxidation. However, the physicochemical conditions in single and sequential extraction experiments (strong reagents and rapid reactions) often differ from natural conditions (weak reagents and slow reactions) [13]. Although leaching techniques such as column leaching and $\mathrm{pH}_{\text {stat }}$ leaching tests are probably more realistic to field conditions, single sequential extractions can give an indication of the "pools" or "sinks" of trace elements that are potentially available under changing environmental conditions.

From a practical point of view, the main drawbacks of sequential extraction procedures are that they are rather laborious and time-consuming. Moreover, not all the steps in a given procedure are equally important in soil or sediment samples with different composition. Sometimes, one is not interested in the association of a metal with different phases in soil but wants to estimate the environmental risks of trace elements, for example, the availability to plants. In recent years, attempts to improve single and sequential extractions towards higher selectivity and higher operational efficiency has been achieved. With respect to this more problemorientated approach, Maiz et al. [14] proposed a short extraction scheme only considering mobile ("exchangeable": $\mathrm{CaCl}_{2}$ ), mobilizable (DTPA), and residual forms. Gómez Ariza et al. [15] developed an improved extraction scheme for heavily polluted and iron-oxide-rich sediments, using repetitive extractions with $\mathrm{NH}_{2} \mathrm{OH} \cdot \mathrm{HCl} 0.4 \mathrm{~mol} / \mathrm{L}$.

The most common problems with sequential extractions are the nonselectivity of reagents and readsorption phenomena $[16,17]$. Besides the measurement of elements in the extracts, the analysis of the solid phase (X-ray diffraction, energy dispersive spectroscopy, and microprobe analysis), after extraction with a reagent, can give information on the selectivity of the reagent and the completeness of reaction [18-24]. The extraction of model solid phases can also yield information of the selectivity and efficiency of reagents in the different steps of a sequential extraction scheme (e.g., $[15,25,26])$. La Force and Fendorf $[23,24]$ concluded that sequential extractions should not be universally applied to all soils but need to be evaluated on a site basis for a given soil. Therefore, optimization of a given extraction (concentration of reagents, sequence, and reaction time) is required. On the other hand, standardization of these procedures is the only way to achieve comparability when using sequential extractions [27]. In the past decade, much effort has been made to evaluate sequential extraction schemes. The best example is the BCR sequential extraction scheme, a simple 
TABLE 1: Examples of different types of extractions with EDTA salts applied to soils and sediments.

\begin{tabular}{llccllc}
\hline Extractant & Applied to & $t$ & $\mathrm{~L} / \mathrm{S}$ & {$[\mathrm{conc}]$} & Metals analyzed & Reference \\
\hline$\left(\mathrm{NH}_{4}\right)_{4}$-EDTA & Sediments & $1 \mathrm{~h}$ & & $10 \mathrm{mmol} / \mathrm{L}$ & & {$[38]$} \\
\hline $\mathrm{Na}_{2} \mathrm{H}_{2}$-EDTA & Soils & $2 \mathrm{~h}$ & 5 & $10 \mathrm{mmol} / \mathrm{L}$ & $\mathrm{Cd}, \mathrm{Zn}, \mathrm{Pb}, \mathrm{Cu}$, and Ni & {$[37]$} \\
\hline $\mathrm{Na}_{2} \mathrm{H}_{2}$-EDTA & Calcareous soils & $22 \mathrm{~h}$ & 10 & $250 \mathrm{mmol} / \mathrm{L}$ & $\mathrm{Cd}, \mathrm{Pb}, \mathrm{Zn}$, and As & {$[39]$} \\
$\mathrm{Na}_{4}$-EDTA & & $24 \mathrm{~h}$ & 5 & $68.4,13.7$ and $27.4 \mathrm{mmol} / \mathrm{L}$ & $\mathrm{Cd}, \mathrm{Pb}, \mathrm{Zn}$, and $\mathrm{Cu}$ & {$[41]$} \\
\hline $\mathrm{H}_{4}$-EDTA & Urban soils & & & $\mathrm{Pb}$ & {$[42]$} \\
\hline $\mathrm{Na}_{2}$ Ca-EDTA & Calcareous soils & & & & & \\
\hline
\end{tabular}

3 -stage procedure that was thoroughly tested by interlaboratory trials. The original procedure [28] consisted of 3 extractions that separated "acid extractable" $\left(\mathrm{CH}_{3} \mathrm{COOH} 0.11 \mathrm{M}\right)$, "reducible" $\left(\mathrm{NH}_{2} \mathrm{OH} \cdot \mathrm{HCl} 0.1 \mathrm{M}, \mathrm{pH} 2\right)$, and "oxidizable" $\left(\mathrm{H}_{2} \mathrm{O}_{2} 15 \%\right)$ fractions. During the certification of reference materials $[29,30]$, the reducing extraction $\left(\mathrm{NH}_{2} \mathrm{OH} \cdot \mathrm{HCl}\right)$ in the BCR sequential extraction scheme was found to suffer from a lack of reproducibility. After testing different reaction conditions (concentration of the reagent, $\mathrm{pH}$ ), the $\mathrm{NH}_{2} \mathrm{OH} \cdot \mathrm{HCl}$ concentration was changed to $0.5 \mathrm{M}$ and the $\mathrm{pH}$ of the reagent was adjusted to 1.5 by the addition of a fixed volume of $\mathrm{HNO}_{3}$.

Finally, different extraction procedures, applied on the same sample, are often compared to select the procedure that is most suited for the soil or sediment of concern (e.g., [15]). However, the direct comparison between methods is difficult to carry out, especially when different reagents are applied to extract a specific phase or when reagents with different concentrations are used in the methods to be compared.

1.4. Single Extractions Applied in the Present Study. Single extractions represent a relatively fast, cheap, and simple way to assess trace element mobility in contaminated soils and sediments. Depending on the objectives of the extraction, water, diluted salt solutions, or stronger reagents such as EDTA are used. Single extractions are also widely applied in soil science for the quantification of the amount of $\mathrm{Fe}$ and $\mathrm{Al}$ oxides in soils. Gupta et al. [31] presented a risk assessment and risk management guideline concept to handle contaminated soils or sites. Mobile and mobilizable metal fractions were introduced, which can be separated by means of single extractions. These fractions are operationally defined by the method used to separate them. The mobile fraction is equivalent to the "actually available" metal fraction, while the mobilizable fraction is related with the potential availability of trace elements in soils and sediments.

1.4.1. EDTA. EDTA extractions are often used to estimate the potentially available pool (i.e., the pool that can deliver metals from the solid phase of the soil to the soil solution in a relatively short time period). EDTA exhibits a strong capacity to complex metals. EDTA was shown to dissolve carbonates, thereby mobilizing occluded elements [32]. Borggaard [33] showed that EDTA extracts amorphous Fe oxides, but this dissolution is very slow in the presence of other metal-chelate complexes [34]. It is also able to form organometal complexes, which compete with organic matter in soil. Several authors mention that an extraction with EDTA provides results similar to the sum of all of the extractable metals in a sequential extraction scheme (total content minus the load associated with the residual phase) [35].

Different types of EDTA salts are used to extract soils and sediments, in different concentrations and at different solid/liquid ratios. Additionally, EDTA can be applied to soils and sediments by percolation in column leaching tests (e.g., $[36,37])$ or in batch extractions. Some examples of the different operational conditions of batch EDTA extractions are given in Table 1. Sodium-EDTA and ammonium-EDTA are the most frequently used EDTA salts, whereas EDTA as a free acid is rarely used to extract soils and sediments.

Zou et al. [38] investigated the influence of different EDTA salts (EDTA free acid, Na-EDTA, and $\mathrm{NH}_{4}$-EDTA) at different concentrations and $\mathrm{pH}$ values. The extraction efficiency of EDTA decreased with increasing $\mathrm{pH}$ in the $\mathrm{pH}$ range $2-10$, and consecutive extractions with diluted EDTA solutions are more effective than a single extraction with a concentrated solution [38]. The tetrasodium salt $\left(\mathrm{Na}_{4}-\right.$ EDTA) is less effective for heavy metal removal compared to the disodium salt $\left(\mathrm{Na}_{2} \mathrm{H}_{2}\right.$-EDTA) [39]. According to Finžgar and Leštan [40], multiple dosages of EDTA were substantially more effective for leaching $\mathrm{Pb}$ from contaminated soils than using one large single dose. Similarly, two extractions with EDTA ( $5 \mathrm{mmol}$ EDTA $/ \mathrm{kg}$ ) removed more $\mathrm{Cu}$ than a single dose of $10 \mathrm{mmol} / \mathrm{kg}$ EDTA.

Additionally, besides the type of EDTA salt, the $\mathrm{pH}$, and the liquid/solid ratio, time is an important variable that influences the results of EDTA extractions. Bermond and Ghestem [43] used a kinetic fractionation method to monitor the EDTA extraction of soil elements versus time. They assumed the existence of two sorts of metallic cations, that is, labile cations-that were quickly extracted, and the slowly or moderately labile cations that were less quickly released. The reactions were considered as pseudo-first-order reactions since the EDTA reagent was in excess and described by a first-order equation [44].

The effectiveness of EDTA salts to extract trace elements from soils and sediments is very variable, not only depending on extraction conditions but also on the composition of soils and sediments and on the speciation of trace elements.

Because of the relatively low cost of EDTA, soil washing with EDTA, both as an in situ and ex situ remediation technique, has been evaluated by many researchers. 
EDTA can effectively remove $\mathrm{Cd}, \mathrm{Cu}, \mathrm{Pb}$, and $\mathrm{Zn}$ from soils with removal efficiencies ranging between 65 and $86 \%$ [45]. However, due to possible adverse health and environmental effects, the use of EDTA is currently under scrutiny. Kalf et al. [46] determined the maximum permissible concentration (MPC) and negligible concentration (NC) for EDTA in water, based on the EU risk assessment report for this compound. The maximum permissible concentration (MPC) for EDTA in water is $2.2 \mathrm{mg} / \mathrm{L}$, and the negligible concentration (NC) is $0.022 \mathrm{mg} / \mathrm{L}$. Calculation of MPCs for sediment or soil was not possible due to the complex speciation of EDTA in soils and sediments.

Since the toxic wastewaters that are generated during soil washing with EDTA cannot be treated using conventional methods such as filtration, flocculation, and precipitation [47], several methods such as electrochemical advanced oxidation [48] or resin trapping techniques [41] have been tested to recuperate the washing solutions or to clean the wastewaters containing EDTA.

1.4.2. Acetic Acid. Extractions with acetic acid or with acetate salts are often carried out as one of the first steps in a sequential extractions scheme. A $1 \mathrm{~mol} / \mathrm{L}$ sodium acetate solution, acidified to $\mathrm{pH} 5$, and $0.11 \mathrm{~mol} / \mathrm{L}$ acetic acid are the most widely used reagents to determine "acid extractable" metal concentrations in sequential extractions schemes: sodium acetate is used to determine the "carbonate fraction" in the Tessier sequential extraction procedure [49], whereas the first step of the BCR sequential extraction procedure [50] consists of an extraction with $0.11 \mathrm{~mol} / \mathrm{L}$ acetic acid.

One of the major parameters that influence the selectivity of reagents during single and sequential extractions is the $\mathrm{pH}$ of the extracts. $0.11 \mathrm{~mol} / \mathrm{L}$ acetic acid (step 1 in the BCR sequential extraction scheme) is supposed to release "exchangeable" elements and to dissolve some poorly crystalline hydroxy- and carbonate-metal phases [32]. It is of major concern that this extraction is as complete as possible since $\mathrm{pH}$ and changes in $\mathrm{pH}$ during extractions are key parameters that determine the potential redistribution of trace elements during (sequential) extractions [43]. The extraction with acetic acid $0.43 \mathrm{~mol} / \mathrm{L}$ allows an estimation of the metal fraction remobilized after acidification of the soil to the $\mathrm{pH}$ of the extracting agent [51].

1.4.3. Single Extractions of the SMぬT Program. The European Standards, Measurements and Testing program (SMT), formerly BCR (European Community Bureau of Reference in Brussels) supports standardization. Between 1996 and 2000, BCR has sponsored studies of soil extraction procedures for trace element speciation conducted by a Working Group of some 35 European laboratories. These studies included the evaluation of single extracting agents for trace element speciation. Within the framework of harmonization of leaching procedures for risk assessment of trace elements in soils, the SM\&T performed an extensive collaborative study, which resulted in the selection of ammonium-EDTA $0.05 \mathrm{~mol} / \mathrm{L}$ and $\mathrm{CH}_{3} \mathrm{COOH} 0.43 \mathrm{~mol} / \mathrm{L}$ (extract the "mobilizable fractions," indicating the "potential availability") as soil extracting agents [50].
In the present study, "potentially mobile" fractions of trace elements in a set of 72 sediment samples with different degree of contamination, major element composition, grain size, organic carbon content, and $\mathrm{pH}$, were separated by means of single extractions that were recommended by the SM\&T of the European Commission. The results of both extractions were compared, and the relationships between the extractability of trace elements and the composition of the sediments samples (degree of contamination, major element composition, grain size, organic carbon content, and $\mathrm{pH}$ ) were investigated and quantified when possible. Finally, different possible uses and interpretations of the acetic acid and ammonium-EDTA extractable trace element fraction are critically discussed.

\section{Methodology}

2.1. Sampling and Sample Pretreatment. The samples analyzed in this study consist of river sediments, alluvial soil samples (land disposed dredged sediments and overbank sediments) from 10 different locations in Flanders (Northern Belgium). Throughout this paper, the term "sediment" will be used to indicate both the river sediments and the alluvial soils that consist of dredged-sediment derived soils and overbank sediments. The river sediments (3 samples) were sampled with a Van Veen Grab, taking the uppermost $5 \mathrm{~cm}$ of the sediment surface. For the alluvial soil samples, profile pits were dug until the depth of the water table and 3 to 5 samples were taken, depending on visual differences in color and texture. During sampling, precaution was taken to minimize metal contamination from the grab or the spade, for example, the outer part of the sediment sample was removed and only the inner part was further processed. In total, 72 samples were collected in plastic bags and transported to the laboratory, where they were air-dried. For the physicochemical analysis, part of the sample was gently disaggregated in a porcelain mortar and sieved $(<2 \mathrm{~mm})$.

2.2. Physicochemical Sample Characteristics. $\mathrm{pH}\left(\mathrm{H}_{2} \mathrm{O}\right)$ was measured in a soil/water suspension $(1 / 2.5 \mathrm{~kg} / \mathrm{L})(\mathrm{pH}$ Hamilton single-pore electrode). Organic carbon was determined according to the Walkley and Black method [52], and effective cation exchange capacity (CEC) was analysed for applying the "silver thiourea method" [53, 54]. Grain size composition was determined by means of laser diffraction spectrophotometry (Malvern Mastersizer S long bed, Malvern, Worcestershire, UK). For practical reasons, CEC and grain size distribution analysis were only performed on 34 samples. Total element concentrations (Al, As, Cd, Co, Cr, $\mathrm{Cu}, \mathrm{Ni}, \mathrm{Pb}, \mathrm{Zn}, \mathrm{Fe}, \mathrm{Mg}, \mathrm{Mn}, \mathrm{K}$, and $\mathrm{Ca}$ ) were determined after dissolution of the samples with a mixture of three concentrated acids $\left(4 \mathrm{~mL} \mathrm{HCl}_{\text {conc }}, 2 \mathrm{~mL} \mathrm{HNO} 3\right.$ conc , and $2 \mathrm{~mL}$ $\left.\mathrm{HF}_{\text {conc }}\right)$.

2.3. Reagents. All reagents used were of analytical grade Suprapur quality (acetic acid from Riedel-de Haën, $\mathrm{NH}_{3}$ and EDTA from Merck).

The $0.05 \mathrm{~mol} / \mathrm{L}$ ammonium-EDTA extracting solution was prepared as an ammonium salt solution by adding in 
a fume cupboard $146.12 \pm 0.05 \mathrm{~g}$ of EDTA free acid to $800 \pm$ $20 \mathrm{~mL}$ distilled water and by partially dissolving by stirring in $130 \pm 5 \mathrm{~mL}$ of concentrated ammonia solution until all the EDTA was dissolved. The obtained solution was filtered $(2.0 \mu \mathrm{m})$ into a 10-litre polyethylene container and diluted with water to $9.0 \pm 0.5 \mathrm{~L}$. The $\mathrm{pH}$ was adjusted to $7.00 \pm 0.05$ by addition of a few drops of hydrochloric acid. Finally, the solution was diluted with distilled water to $10 \pm 0.1 \mathrm{~L}$, well mixed, and then stored in stoppered polyethylene container.

The $0.43 \mathrm{~mol} / \mathrm{L}$ acetic acid extracting solution was prepared by adding $250 \pm 2 \mathrm{~mL}$ of redistilled glacial acetic acid in a fume cupboard to about 5 litres of distilled water in a $10 \mathrm{~L}$ polyethylene container. The solution was diluted with distilled water to $10 \mathrm{~L}$ volume, well mixed, and then stored in a stoppered polyethylene container.

Standard solutions for FAAS were made by serial dilution of $1000 \mu \mathrm{g} / \mathrm{L}$ standard solutions (Merck) of the appropriate elements. Standard series for ICP-MS were made, starting from the " $10 \mathrm{ppm}$ multielement calibration standard $2 \mathrm{~A}$ in $5 \% \mathrm{HNO}_{3}$ " from Hewlett Packard.

2.4. Single Extractions. For the ammonium-EDTA and acetic acid extraction, the protocol of the SM\&T program [27] was followed. $20 \mathrm{~mL}$ of a $0.05 \mathrm{~mol} / \mathrm{L}$ ammonium-EDTA solution was added to $2 \mathrm{~g}$ of dry sediment. The suspension was shaken for $1 \mathrm{~h}$ in a reciprocal shaker, centrifuged ( $3500 \mathrm{rpm}, 10 \mathrm{~min}$ ), decanted off, and filtered $(0.45 \mu \mathrm{m}) .40 \mathrm{~mL}$ of a $0.43 \mathrm{~mol} / \mathrm{L}$ $\mathrm{CH}_{3} \mathrm{COOH}$ solution was added to $1 \mathrm{~g}$ of dry sediment. The suspension was shaken for $16 \mathrm{~h}$ in a reciprocal shaker, centrifuged (3500 rpm, $10 \mathrm{~min}$ ), decanted, and then filtered $(0.45 \mu \mathrm{m})$. After measuring the $\mathrm{pH}$, the $\mathrm{CH}_{3} \mathrm{COOH}$ extracts were acidified with concentrated $\mathrm{HNO}_{3}$ to bring the $\mathrm{pH}<$ 2. The EDTA extracts were not acidified prior to analysis to prevent precipitation of EDTA salts at very low $\mathrm{pH}$. A Reference material (CRM 483) certified for its ammoniumEDTA and acetic acid extractable content of $\mathrm{Cd}, \mathrm{Cr}, \mathrm{Cu}$, $\mathrm{Ni}, \mathrm{Pb}$, and $\mathrm{Zn}$ was also included in quadruplate. Blank extractions (i.e., without soil or sediment) were carried out for each set of analysis, using the same reagents as described above.

2.5. Analysis of the Leachates. The solutions were analysed by flame atomic adsorption spectrometry (FAAS) (Varian Techtron AA6) for $\mathrm{Ca}, \mathrm{Fe}, \mathrm{K}$, and $\mathrm{Al}$. For As, $\mathrm{Cd}, \mathrm{Cr}, \mathrm{Cu}, \mathrm{Mn}$, $\mathrm{Ni}, \mathrm{Pb}$, and $\mathrm{Zn}$ a multielement analysis by ICP-MS (HP 4500 series) was carried out. All samples were diluted with $\mathrm{HNO}_{3}$ $1 \mathrm{~mol} / \mathrm{L}$ (ultra pure) to maintain a comparable matrix for all samples.

For measurement of the single extraction leachates, standard solution series were made in such away that they contained the same proportion of the respective extraction solution and background. All glassware was thoroughly cleaned with $\mathrm{HNO}_{3} 0.15 \mathrm{~mol} / \mathrm{L}$. Reagent blanks were determined for each new batch of reagent. Detection limits were calculated according to the procedure in the HP 4500 Application Handbook. Except for $\mathrm{Ca}(10 \mu \mathrm{g} / \mathrm{L})$ and for $\mathrm{Fe}(3 \mu \mathrm{g} / \mathrm{L})$, the detection limit was generally below $1 \mu \mathrm{g} / \mathrm{L}$. An indium (In) internal standard was applied to both samples and standards to minimise the influence of nonspectroscopic interferences such as signal suppression or enhancement when measuring samples with a high matrix concentration. The spectroscopic interference of $\mathrm{ArCl}$, which has the same $\mathrm{m} / \mathrm{z}$ as As (75), was corrected according to the recommendations of the US Environmental Protection Agency (EPA) (method 200.8, [55]). The $\mathrm{pH}$ of the extracts was measured with a $\mathrm{pH}$ Hamilton single-pore electrode.

2.6. Statistical Analysis. Statistical analysis was performed with the software package SPSS 18.0 for Windows. Descriptive statistics (average, median, minimum, maximum, and standard deviation) were calculated for each variable. The normal distribution of the variables was checked by means of the Kolmogorov-Smirnov (K-S) test, and correlations between variables were tested by calculating two-tailed Pearson's correlation coefficients. An $\alpha$-value of 0.01 was adopted at the critical level for all statistical testing, giving a $99 \%$ confidence level. One-way ANOVA was performed to investigate whether there was a difference between both reagents concerning the ability to extract elements from the sediments.

Finally, stepwise multiple linear regression was performed to deduce possible causal relationships between the variables. Attention was mainly paid to the possibility of predicting trace element concentrations in the ammonium-EDTA and acetic acid extracts based on trace element content, major element composition, $\mathrm{pH}$, and organic matter content. Different assumptions of the linear regression (normality of the de residues, autocorrelation, quasi-multicollinearity (QMC), and heteroscedasticity) were tested.

For the statistical analysis, the recommendations of Webster [56, 57] (reporting mean values with standard errors, performing linear regressions, etc.) were taken into account.

\section{Results and Discussion}

3.1. Certified Reference Materials. Certified reference materials, which are also called standard reference materials, are used for the verification of the accuracy of analytical procedures following strict extraction protocols [58]. In the present work, single extractions (with ammonium-EDTA $0.05 \mathrm{~mol} / \mathrm{L}$, acetic acid $0.43 \mathrm{~mol} / \mathrm{L}$ ) were performed on two certified reference materials that were developed within the framework of the SM\&T program, namely, BCR 701 and CRM483.

Total concentrations of $\mathrm{Cd}, \mathrm{Cr}, \mathrm{Cu}, \mathrm{Ni}, \mathrm{Pb}$, and $\mathrm{Zn}$ were determined in reference material BCR-701 [59] by dissolution with 3 concentrated acids ( $\mathrm{HF}, \mathrm{HCl}$, and $\mathrm{HNO}_{3}$ ) (Table 2). Although the extraction procedure is different from the aqua regia extraction, the own values were within 1 standard deviation of the indicative values, except for $\mathrm{Cu}$.

CRM 483 is a sewage-sludge amended soil that was collected by multiple sampling to a depth of $10 \mathrm{~cm} \mathrm{[60].} \mathrm{Within}$ the framework of harmonization of leaching procedures for risk assessment of trace elements in soils (SMT program), the reference material CRM 483 was certified for its ammoniumEDTA and acetic acid extractable contents [28]. 
TABle 2: Comparison between aqua regia extractable (indicative values) and " 3 -acid" extractable (this work) concentrations $(\mathrm{mg} / \mathrm{kg}$ ) of $\mathrm{Cd}, \mathrm{Cr}, \mathrm{Cu}, \mathrm{Ni}, \mathrm{Pb}$, and $\mathrm{Zn}$ in sample BCR 701. Mean \pm standard deviation of 3 replicates.

\begin{tabular}{lcc}
\hline & Indicative values & This work \\
\hline $\mathrm{Cd}$ & $11.7 \pm 1.0$ & $10.9 \pm 0.2$ \\
$\mathrm{Cr}$ & $272 \pm 20$ & $284 \pm 5$ \\
$\mathrm{Cu}$ & $275 \pm 13$ & $242 \pm 2$ \\
$\mathrm{Ni}$ & $103 \pm 4$ & $99 \pm 7$ \\
$\mathrm{~Pb}$ & $143 \pm 6$ & $141 \pm 3$ \\
$\mathrm{Zn}$ & $454 \pm 19$ & $465 \pm 4$ \\
\hline
\end{tabular}

TABle 3: Comparison of the results of the ammonium-EDTA and acetic acid extractions of CRM 483 with certified and indicative values [31]. The number of replicates is given between brackets. Concentrations in $\mathrm{mg} / \mathrm{kg}$.

\begin{tabular}{lcc}
\hline CRM483 & \multicolumn{2}{c}{ Certified values [31] } \\
\hline $\mathrm{Cd}$ & Ammonium-EDTA & Acetic acid \\
$\mathrm{Cr}$ & $20.4 \pm 1.3$ & $18.3 \pm 0.6$ \\
$\mathrm{Cu}$ & $28.6 \pm 2.6$ & $18.7 \pm 1.0$ \\
$\mathrm{Ni}$ & $215 \pm 11$ & $33.5 \pm 1.6$ \\
$\mathrm{~Pb}$ & $28.7 \pm 1.7$ & $25.8 \pm 1.0$ \\
$\mathrm{Zn}$ & $229 \pm 8$ & $3.1 \pm 0.25$ \\
$\mathrm{CRM} 483$ & $612 \pm 19$ & $620 \pm 24$ \\
\hline \multicolumn{3}{c}{ This work } \\
$\mathrm{Cd}$ & Ammonium-EDTA (6) & Acetic acid $(6)$ \\
$\mathrm{Cr}$ & $20.6 \pm 0.6$ & $15.2 \pm 1.48$ \\
$\mathrm{Cu}$ & $26.4 \pm 3.4$ & $13.3 \pm 1.95$ \\
$\mathrm{Ni}$ & $207 \pm 4$ & $28.1 \pm 0.46$ \\
$\mathrm{~Pb}$ & $26.5 \pm 1.78$ & $21.5 \pm 0.77$ \\
$\mathrm{Zn}$ & $202 \pm 27$ & $1.7 \pm 0.21$ \\
\hline
\end{tabular}

A good agreement was obtained between the own and indicative/certified values for the ammonium-EDTA extractions (Table 3). Experimental values always differed by less than 1 standard deviation from the certified values.

The results of the acetic acid extraction, however, were systematically lower than the certified values. This can be related to the fact that a reciprocal shaker was used instead of an end-over-end shaker, as recommended by the SM\&T procedure. The shaker speed and the use of an end-over-end shaker (instead of a reciprocal shaker) are considered to be important parameters since they represent factors that condition the maintenance of the samples in suspension during extraction. During the comparison of trace element extractability in sample CRM 483, the results obtained from the reciprocal shaker were systematically too low [31]. Therefore, the centrifuge bottles were placed in the shaking device with an inclination of approximately $45^{\circ}$. This modification allowed a better suspension of the sediments during extraction. For the ammonium-EDTA extraction, for which $2 \mathrm{~g}$ of material was suspended in $20 \mathrm{~mL}$ of solution in a $50 \mathrm{~mL}$ centrifuge tube, the samples were maintained in suspension during extraction. However, during the acetic acid extraction, $1 \mathrm{~g}$ of material was suspended in $40 \mathrm{~mL}$ of solution in a $50 \mathrm{~mL}$ centrifuge tube, resulting in a less efficient suspension of the material because of the higher amount of liquid in the centrifuge tube. This may explain the deviating results of the acetic acid extractions.

3.2. General Sample Characteristics. The 72 samples represent a variety of sediments with different contents of major elements, trace elements, organic carbon, and $\mathrm{pH}$. The $\mathrm{pH}$ of the samples investigated in this study was in the range 5.3-8.1 (Table 4). The grain size distribution of the samples varied from clayey to sandy, and cation exchange capacity (CEC) was between 7 and $38 \mathrm{cmol} / \mathrm{kg}$ (not in Table 4). A significant positive linear correlation $(R=0.760)$ was found between $\mathrm{CEC}$, on the one hand, and the organic carbon and $\mathrm{Al}$ content (which can be used as a proxy for the clay content), on the other hand. Since CEC was not determined for all the samples, it was not included in the further analysis of the dataset. All the samples were polluted with at least one of the following trace elements: $\mathrm{Zn}, \mathrm{Cd}, \mathrm{Pb}, \mathrm{Cu}, \mathrm{As}$, and/or $\mathrm{Ni}$. Significant correlations were found ( 0.01 significance level) between most trace elements $(\mathrm{Cr}, \mathrm{Cu}, \mathrm{Zn}, \mathrm{Ni}, \mathrm{Cd}, \mathrm{Pb}$, and $\mathrm{Co}$, $R=0.805-0.382)$. Ca and $\mathrm{pH}$ were also positively correlated $(R=0.789)$, as well as Fe and the organic carbon content $(R=$ $0.456)$ and $\mathrm{Ca}$ and $\mathrm{pH}(R=0.860)$.

With respect to the extraction with ammonium-EDTA, $\mathrm{Zn}, \mathrm{Cd}, \mathrm{Cu}, \mathrm{Ni}$, and As correlated positively with each other, whereas the correlation between $\mathrm{pH}$ and EDTA-extractable $\mathrm{Al}$ and $\mathrm{Fe}$ was negative. Finally, for the acetic acid extraction, a positive correlation was found between the extracted concentrations of $\mathrm{Cr}, \mathrm{Cu}, \mathrm{Zn}, \mathrm{Co}$, and $\mathrm{Mn}$.

3.3. Extraction Efficiency. Single extractions with acetic acid and ammonium-EDTA provide some information on the influence of acidification and complexation on trace element mobility. In general, $\mathrm{Zn}, \mathrm{Cd}$, and Ni were sensitive to both acetic acid and ammonium-EDTA, whereas $\mathrm{Pb}$ and $\mathrm{Cu}$ were more sensitive to an extraction with ammonium-EDTA. The highest average extraction efficiency with acetic acid was obtained for $\mathrm{Cd}$ and $\mathrm{Zn}$, while $\mathrm{Cu}$ was most effectively extracted with ammonium-EDTA.

The extraction efficiency of both extracting agents was compared in order to assess their ability to release metals from the "weakly bound" element pool of the sediments.

The results from the one-way ANOVA (Table 6) showed that there were significant differences between both extracting agents for $\mathrm{Cu}, \mathrm{Pb}$, and $\mathrm{Co}$ and for most of the major elements, such as $\mathrm{Fe}, \mathrm{Al}$, and $\mathrm{Ca}$. For $\mathrm{Cd}, \mathrm{Zn}, \mathrm{Ni}, \mathrm{As}, \mathrm{Cr}$, and $\mathrm{Mn}$ there was a similarity between ammonium-EDTA and acetic acid as an extracting agent. Nevertheless, the yields for Cr were negligible.

From Figure 1, it can be deduced that comparable amounts of $\mathrm{Zn}$ and $\mathrm{Ni}$ are extracted with both reagents. Slightly more Cd was extracted with acetic acid compared to ammonium-EDTA, while for the trace elements $\mathrm{Cu}$ and $\mathrm{Pb}$, ammonium-EDTA was a more effective extracting 
TABle 4: Average, standard deviation, median, minimum, and maximum of the amounts of major and trace metals, the organic carbon (OC) content, and the $\mathrm{pH}$ in the 72 sediments investigated in this study.

\begin{tabular}{lccccccccccccccc}
\hline & $\begin{array}{c}\mathrm{Cr} \\
\mathrm{mg} / \mathrm{kg}\end{array}$ & $\begin{array}{c}\mathrm{Cu} \\
\mathrm{mg} / \mathrm{kg}\end{array}$ & $\begin{array}{c}\mathrm{Zn} \\
\mathrm{mg} / \mathrm{kg}\end{array}$ & $\begin{array}{c}\mathrm{Ni} \\
\mathrm{mg} / \mathrm{kg}\end{array}$ & $\begin{array}{c}\mathrm{As} \\
\mathrm{mg} / \mathrm{kg}\end{array}$ & $\begin{array}{c}\mathrm{Cd} \\
\mathrm{mg} / \mathrm{kg}\end{array}$ & $\begin{array}{c}\mathrm{Pb} \\
\mathrm{mg} / \mathrm{kg}\end{array}$ & $\begin{array}{c}\mathrm{Co} \\
\mathrm{mg} / \mathrm{kg}\end{array}$ & $\begin{array}{c}\mathrm{Mn} \\
\mathrm{mg} / \mathrm{kg}\end{array}$ & $\begin{array}{c}\mathrm{K} \\
\mathrm{mg} / \mathrm{kg}\end{array}$ & $\begin{array}{c}\mathrm{Fe} \\
\%\end{array}$ & $\begin{array}{c}\mathrm{Ca} \\
\%\end{array}$ & $\begin{array}{c}\mathrm{Al} \\
\%\end{array}$ & $\begin{array}{c}\mathrm{OC} \\
\%\end{array}$ & $\begin{array}{c}\mathrm{pH} \\
\text { Average }\end{array}$ \\
\hline 131 & 65 & 706 & 29 & 80 & 18 & 124 & 7.9 & 273 & 12265 & 6 & 2 & 3 & 6.2 & 6.7 \\
Stdv & 99 & 71 & 959 & 23 & 92 & 37 & 162 & 5.2 & 342 & 7106 & 5 & 1 & 1 & 4.1 & 0.8 \\
Median & 95 & 45 & 442 & 27 & 42 & 9 & 69 & 8.0 & 172 & 11070 & 3 & 2 & 3 & 5.3 & 6.7 \\
Min & 28 & 1 & 14 & 3 & 4 & 0.1 & 4 & 1.3 & 23 & 3248 & 1 & 0.2 & 1 & 0.5 & 5.3 \\
Max & 529 & 286 & 5086 & 117 & 516 & 198 & 756 & 24.0 & 2555 & 46479 & 23 & 5 & 5 & 19.5 & 8.1 \\
\hline
\end{tabular}

TABle 5: Average, standard deviation, median, minimum, and maximum of the amounts of major and trace metals extracted with acetic acid and ammonium-EDTA.

\begin{tabular}{|c|c|c|c|c|c|c|c|c|c|c|c|c|c|c|}
\hline \multicolumn{15}{|c|}{ Acetic acid } \\
\hline & $\begin{array}{c}\mathrm{Cr} \\
\mathrm{mg} / \mathrm{kg}\end{array}$ & $\begin{array}{c}\mathrm{Cu} \\
\mathrm{mg} / \mathrm{kg}\end{array}$ & $\begin{array}{c}\mathrm{Zn} \\
\mathrm{mg} / \mathrm{kg}\end{array}$ & $\begin{array}{c}\mathrm{Ni} \\
\mathrm{mg} / \mathrm{kg}\end{array}$ & $\begin{array}{c}\text { As } \\
\mathrm{mg} / \mathrm{kg}\end{array}$ & $\begin{array}{c}\mathrm{Cd} \\
\mathrm{mg} / \mathrm{kg}\end{array}$ & $\begin{array}{c}\mathrm{Pb} \\
\mathrm{mg} / \mathrm{kg}\end{array}$ & $\begin{array}{c}\mathrm{Co} \\
\mathrm{mg} / \mathrm{kg}\end{array}$ & $\begin{array}{c}\mathrm{Mn} \\
\mathrm{mg} / \mathrm{kg}\end{array}$ & $\begin{array}{c}\mathrm{K} \\
\mathrm{mg} / \mathrm{kg}\end{array}$ & $\begin{array}{c}\mathrm{Fe} \\
\mathrm{mg} / \mathrm{kg}\end{array}$ & $\begin{array}{c}\mathrm{Ca} \\
\mathrm{mg} / \mathrm{kg}\end{array}$ & $\begin{array}{c}\mathrm{Al} \\
\mathrm{mg} / \mathrm{kg}\end{array}$ & $\mathrm{pH}$ \\
\hline Average & 2 & 10.4 & 436 & 8.02 & 3.26 & 8 & 5 & 1.3 & 104 & 338 & 1049 & 11386 & 172 & 3.1 \\
\hline Stdv & 2 & 15.3 & 652 & 8.81 & 5.60 & 13 & 11 & 1.2 & 121 & 786 & 2223 & 8865 & 126 & 0.4 \\
\hline Median & 1 & 3.3 & 197 & 6.34 & 1.49 & 5 & 1 & 1.1 & 74 & 195 & 296 & 7846 & 145 & 3.1 \\
\hline Min & $<0.01$ & $<0.01$ & 4 & $<0.01$ & 0.05 & 0.1 & $<0.01$ & 0.1 & 2 & 65 & 47 & 1126 & 28 & 2.2 \\
\hline Max & 10 & 77.0 & 3574 & 43.88 & 26.96 & 69 & 65 & 4.8 & 592 & 6788 & 13143 & 38694 & 844 & 3.6 \\
\hline \multicolumn{15}{|c|}{ Ammonium-EDTA } \\
\hline & $\begin{array}{c}\mathrm{Cr} \\
\mathrm{mg} / \mathrm{kg}\end{array}$ & $\begin{array}{c}\mathrm{Cu} \\
\mathrm{mg} / \mathrm{kg}\end{array}$ & $\begin{array}{c}\mathrm{Zn} \\
\mathrm{mg} / \mathrm{kg}\end{array}$ & $\begin{array}{c}\mathrm{Ni} \\
\mathrm{mg} / \mathrm{kg}\end{array}$ & $\begin{array}{c}\text { As } \\
\mathrm{mg} / \mathrm{kg}\end{array}$ & $\begin{array}{c}\mathrm{Cd} \\
\mathrm{mg} / \mathrm{kg}\end{array}$ & $\begin{array}{c}\mathrm{Pb} \\
\mathrm{mg} / \mathrm{kg}\end{array}$ & $\begin{array}{c}\mathrm{Co} \\
\mathrm{mg} / \mathrm{kg}\end{array}$ & $\begin{array}{c}\mathrm{Mn} \\
\mathrm{mg} / \mathrm{kg}\end{array}$ & $\begin{array}{c}\mathrm{K} \\
\mathrm{mg} / \mathrm{kg}\end{array}$ & $\begin{array}{c}\mathrm{Fe} \\
\mathrm{mg} / \mathrm{kg}\end{array}$ & $\begin{array}{c}\mathrm{Ca} \\
\mathrm{mg} / \mathrm{kg}\end{array}$ & $\begin{array}{c}\mathrm{Al} \\
\mathrm{mg} / \mathrm{kg}\end{array}$ & $\mathrm{pH}$ \\
\hline Average & 1 & 31 & 419 & 7.76 & 2.4 & 10 & 49 & 0.7 & 50 & 228 & 3176 & 9066 & 68 & 6.3 \\
\hline Stdv & 1 & 43 & 578 & 9.56 & 3.6 & 21 & 81 & 0.6 & 66 & 143 & 2957 & 4478 & 59 & 1.0 \\
\hline Median & 1 & 20 & 216 & 5.65 & 1.2 & 5 & 21 & 0.5 & 41 & 182 & 2039 & 9178 & 50 & 6.4 \\
\hline Min & $<0.01$ & 0.10 & 2 & 0.45 & 0.02 & $<0.01$ & $<0.01$ & $<0.01$ & $<0.01$ & 51 & 176 & 1232 & 8 & 4.6 \\
\hline Max & 6 & 177 & 2539 & 51.67 & 16 & 109 & 389 & 3.3 & 527 & 603 & 11902 & 18718 & 265 & 7.8 \\
\hline
\end{tabular}

agent (Figure 1). Some samples with a high total content of $\mathrm{Zn}$ and $\mathrm{Cd}$, as well as an important EDTA and acetic acid extractable content of $\mathrm{Zn}$ and $\mathrm{Cd}$, distort the general relationship between total and ammonium-EDTA or acetic acid extractable content of $\mathrm{Zn}$ and $\mathrm{Cd}$. Logtransformed concentrations were used in further calculations (see Section 3.2).

The more important release of $\mathrm{Cu}$ and $\mathrm{Pb}$ by ammonium-EDTA compared to acetic acid is related to the fact that EDTA has a much stronger complexing capacity than acetic acid. The stability constants for EDTA and acetic acid complexes with $\mathrm{Cd}, \mathrm{Cu}, \mathrm{Zn}, \mathrm{Ni}$, and $\mathrm{Pb}$ are presented in Table 7. Complexes of $\mathrm{Cd}$ and $\mathrm{Zn}$ with acetate are characterised by significantly lower stability constants than $\mathrm{Pb}$ and $\mathrm{Cu}$, but this does not compensate for the fact that $\mathrm{Zn}$ and $\mathrm{Cd}$ are more easily mobilised upon a $\mathrm{pH}$ decrease compared to $\mathrm{Cu}$ and $\mathrm{Pb}$. The $\mathrm{pH}$ of the acetic acid extract is in the range 2.7-3.5, promoting the release of $\mathrm{Cd}$, $\mathrm{Zn}$, and $\mathrm{Ni}$ while $\mathrm{Cu}$ and $\mathrm{Pb}$ are only released in significant amounts at lower $\mathrm{pH}$ values.

Since the $\mathrm{pH}$ of the ammonium-EDTA extract is fairly constant and almost neutral, trace element release is principally a consequence of complexation reactions. No relationship was found between the formation constants for $1: 1$
EDTA complexes and the slopes of the relation in Figure 1, indicating that the amount of a metal extracted with EDTA is not only determined by the affinity of the metal to form complexes with EDTA. Besides the complexing affinity of a EDTA for a trace element, the affinity between the sediment and a trace element will also control the desorption by the complexing agent.

According to Papassiopi et al. [39], the dissolution of calcite can consume EDTA in calcareous soils, lowering the extraction efficiency for trace elements. In general, major cations present in the soil may be one of the factors affecting trace element extraction efficiency [66]. In the present study, important amounts of Fe and Ca were also extracted with ammonium-EDTA (Table 5), possibly affecting the extraction efficiency of the reagent.

The comparison of "potential availability" of trace elements by different and single extractions (acetic acid or ammonium-EDTA extractions as defined by the SMT program) is not completely straightforward since operational conditions (L/S ratio, extraction time, etc.) and reagents are different. The estimation of the potential (long-term) trace element availability is thus operationally defined by the extracting agents used. van der Sloot et al. [51] mention that the acetic acid and ammonium-EDTA extractions release 
TABLE 6: Results of the one-way ANOVA for the comparison of elements extracted with acetic acid and EDTA (*significant at $P<0.05)$.

\begin{tabular}{lccccc}
\hline & $S S$ & $d f$ & $M S$ & $F$ & 3.15 \\
$\mathrm{Cr}$ & 8.5 & 1 & 8.5 & 15.05 & 0.078 \\
$\mathrm{Cu}$ & 15448 & 1 & 15448 & 0.03 & $0.000^{*}$ \\
$\mathrm{Zn}$ & 9944 & 1 & 9944 & 0.03 & 0.872 \\
$\mathrm{Ni}$ & 2.5 & 1 & 2.5 & 1.18 & 0.863 \\
$\mathrm{As}$ & 26.1 & 1 & 26.1 & 0.45 & 0.279 \\
$\mathrm{Cd}$ & 137.2 & 1 & 137.2 & 21.38 & $0.000^{*}$ \\
$\mathrm{~Pb}$ & 71795 & 1 & 71795 & 18.28 & $0.000^{*}$ \\
$\mathrm{Co}$ & 15.2 & 1 & 15.2 & 11.05 & $0.001^{*}$ \\
$\mathrm{Mn}$ & 104719 & 1 & 104719 & 23.80 & $0.000^{*}$ \\
$\mathrm{Fe}$ & 162860447 & 1 & 162860447 & 3.93 & $0.049^{*}$ \\
$\mathrm{Ca}$ & 193751031 & 1 & 193751031 & 39.76 & $0.000^{*}$ \\
$\mathrm{Al}$ & 387317 & 1 & 387317 & & \\
\hline
\end{tabular}

TABLe 7: Formation constants (log K) for $1: 1$ metal EDTA complexes and $1: 1$ metal acetate complexes.

\begin{tabular}{|c|c|c|c|c|}
\hline & Stability constant for acetic acid & Reference & Stability constant for EDTA & Reference \\
\hline $\mathrm{Cu}^{2+}$ & $1.76,1.87,2.71,3.09,3.63$ & {$[61,62]$} & $19.7,18.8$ & {$[63,64]$} \\
\hline $\mathrm{Zn}^{2+}$ & $0.91,1.9$ & {$[61,62]$} & $17.5,16.5$ & {$[63,64]$} \\
\hline $\mathrm{Ni}^{2+}$ & $0.74,0.83,1.43$ & {$[61,62]$} & $19.5,18.56$ & {$[63,64]$} \\
\hline $\mathrm{Cd}^{2+}$ & $1.19,1.23,1.32,1.82,3.15$ & {$[61,62]$} & 17.4 & {$[63,64]$} \\
\hline $\mathrm{Pb}^{2+}$ & $3.5,2.98,4.08$ & {$[61,62]$} & 19 & {$[63,64]$} \\
\hline $\mathrm{Co}^{2+}$ & 0.71 & [65] & 16.21 & [64] \\
\hline $\mathrm{Mn}^{2+}$ & & & 13.56 & {$[64]$} \\
\hline $\mathrm{Fe}^{3+}$ & & & 25.7 & {$[64]$} \\
\hline $\mathrm{Ca}^{2+}$ & 0.5 & {$[65]$} & 10.7 & {$[64]$} \\
\hline $\mathrm{Al}^{3+}$ & & & 16.3 & {$[64]$} \\
\hline
\end{tabular}

an amount of $\mathrm{Zn}$ and $\mathrm{Cd}$ that is very similar to the amount leached at $\mathrm{pH} 4$ in a $24 \mathrm{~h}$ pHstat test, $\mathrm{L} / \mathrm{S}=5 \mathrm{~L} / \mathrm{kg}$ ). However, this seems to not be the case in a more heterogeneous dataset with samples with very different physicochemical characteristics.

The difference between acetic acid and ammoniumEDTA as an extracting agent is particularly interesting for the metalloid As. Although As is generally more easily mobilized when $\mathrm{pH}$ increases, acetic acid is capable of extracting a considerable amount of As. Even more As is extracted by acetic acid than with ammonium-EDTA, despite the lower final $\mathrm{pH}$ of the acetic acid extract (around Section 3.5). Wenzel et al. [67] also found that only minor proportions of As were extracted by ammonium-EDTA, virtually not contributing to As fractionation. The inefficiency of As extraction by ammonium-EDTA is explained by the fact that EDTA does not form stable complexes with arsenic [68].

3.4. Influence of Sediment Characteristics on Metal Extractability. The lack of a distinct relationship between total and acid extractable metal concentrations in the present dataset is most likely due to the very different physicochemical and mineralogical characteristics of the samples. In a previous study on land-disposed dredged sediments [69], acetic acid
$(0.43 \mathrm{~mol} / \mathrm{L})$ extractable $\mathrm{Zn}$ and $\mathrm{Cd}$ concentrations were linearly correlated with total $\mathrm{Zn}$ and Cd concentrations. All the samples originated from the same river catchment and were characterised by and elevated clay and organic carbon content.

The $\mathrm{pH}$ after extractions with acetic acid $(0.43 \mathrm{~mol} / \mathrm{L})$ was in the range 2.2-3.6. The increase in $\mathrm{pH}$ after extraction (Figure 2) can be related to the acid neutralizing capacity of the samples. The $\mathrm{pH}$ of the EDTA extract was between 4.6 and 7.8 , despite the fact that the ammonium-EDTA solution is a buffered solution. Additionally, the difference in $\mathrm{pH}$ of the acetic acid extracts before and after extraction showed a significant linear correlation with the (log-transformed) total Ca content of the samples. This can simply be explained by the fact that samples with an elevated acid neutralizing capacity (ANC) usually are characterised by a high $\mathrm{CaCO}_{3}$ content, which is an important contributor to acid neutralizing reactions in soils and sediments.

Based on the results of the extractions and on the sediment composition, regression equations were constructed using the ammonium-EDTA or acetic acid extractable content of a trace element $(\mathrm{Cu}, \mathrm{Cr}, \mathrm{Zn}, \mathrm{Ni}, \mathrm{As}, \mathrm{Cd}, \mathrm{Pb}$, or $\mathrm{Co})$ as the dependent variable and the total content of the respective trace element $(\mathrm{Cu}, \mathrm{Cr}, \mathrm{Zn}, \mathrm{Ni}, \mathrm{As}, \mathrm{Cd}, \mathrm{Pb}$, or 


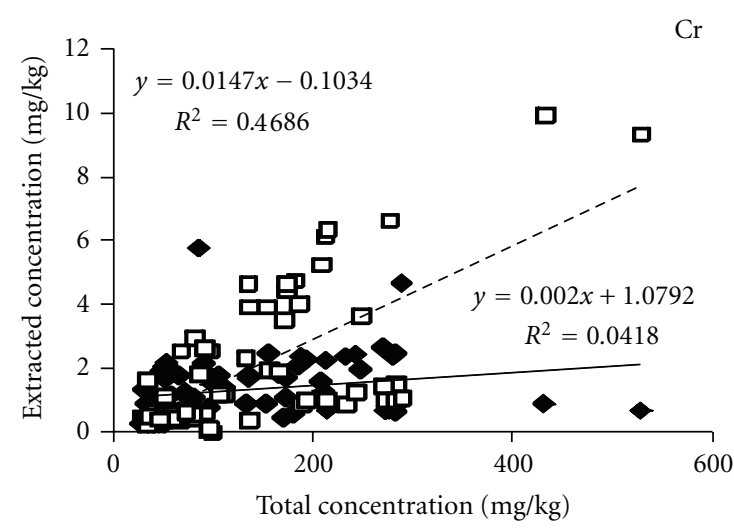

(a)

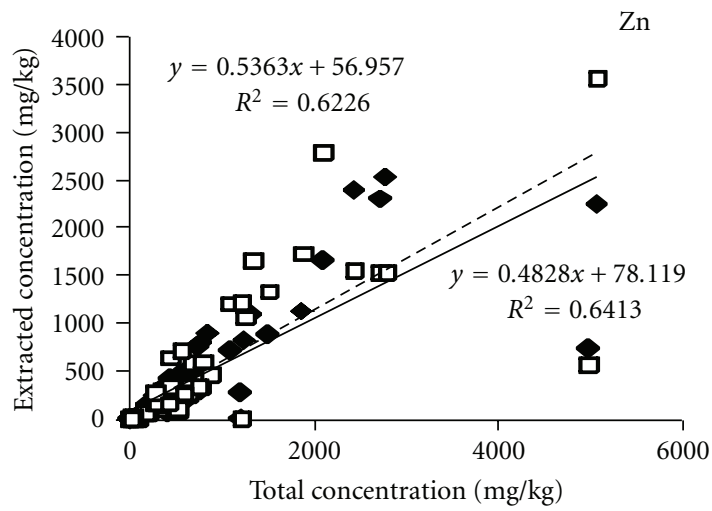

(c)

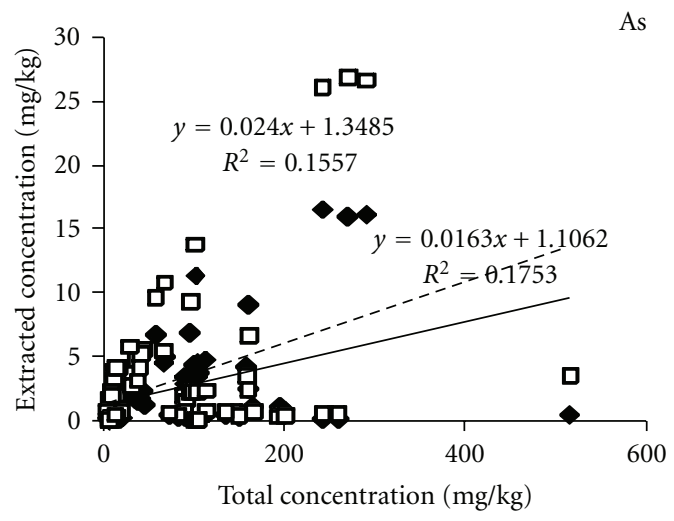

(e)

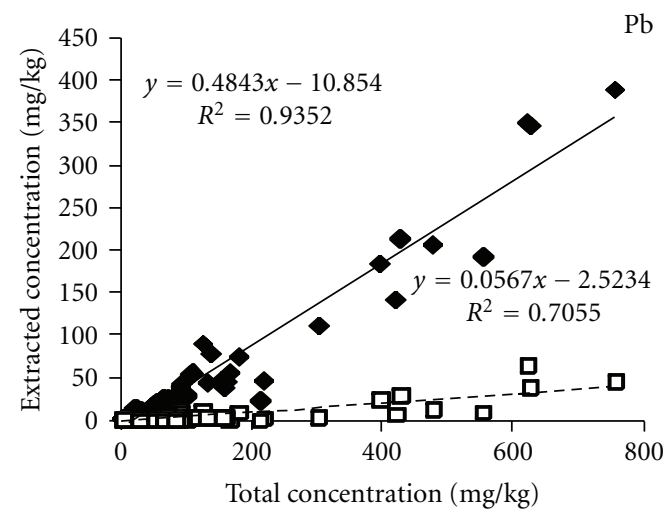

(g)

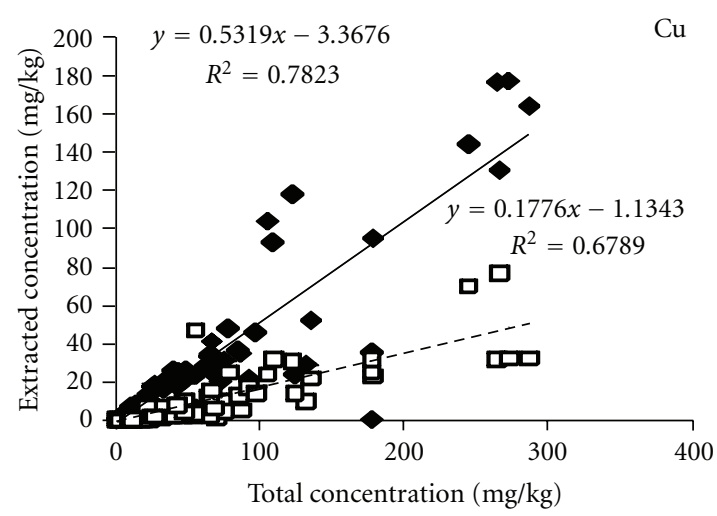

(b)

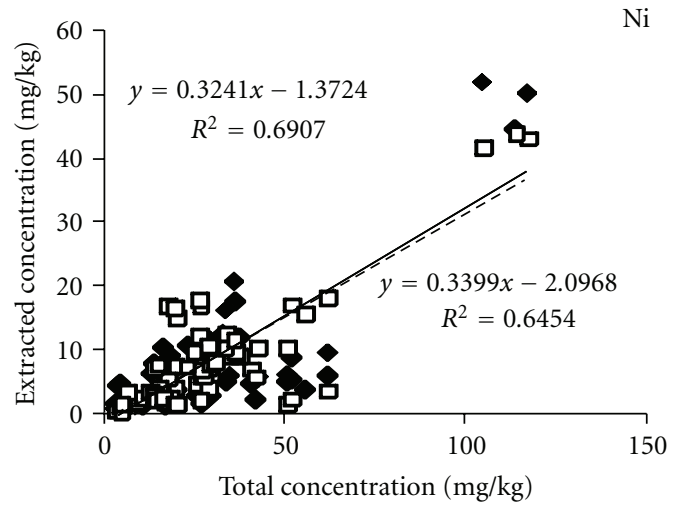

(d)

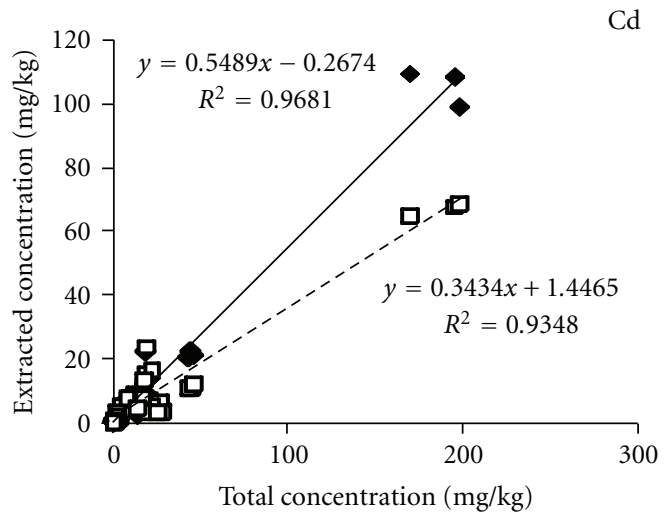

(f)

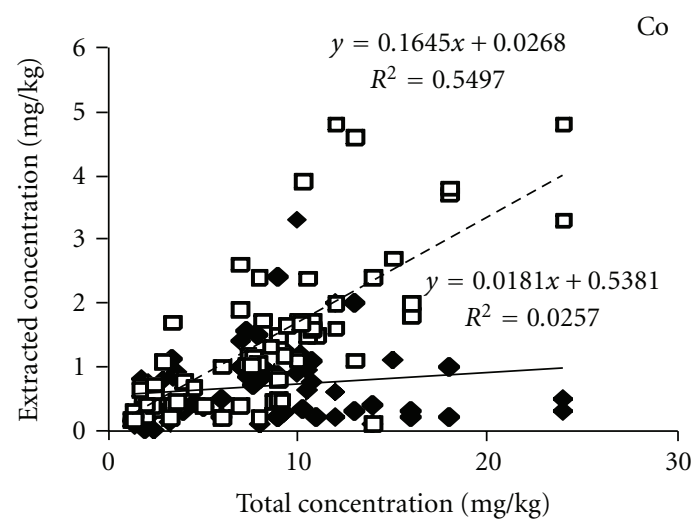

(h)

FIGURE 1: Amount of trace elements extracted by ammonium-EDTA (black symbols and full line) and acetic acid (white symbols and dotted line) as a function of their total content in the sediments. 


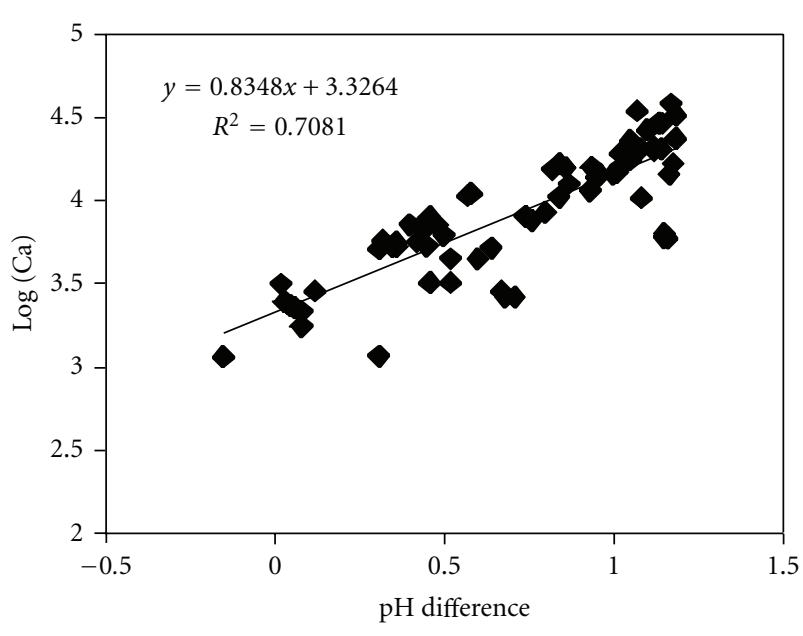

Figure 2: Difference between the $\mathrm{pH}$ of the acetic acid solution before and after extraction versus the amount of Ca released from the samples.

$\mathrm{Co}$ ), the total content of $\mathrm{Ca}, \mathrm{Al}$, and $\mathrm{Fe}$, the $\mathrm{pH}$, and the organic carbon content as independent variables. Because the data were not normally distributed, log-transformed data were used (expect for $\mathrm{pH}$, which is already a logarithmic value). In soils and sediments, $\mathrm{Ca}$ is dominantly found in clay minerals and in carbonate minerals (e.g., $\mathrm{CaCO}_{3}$ ). Fe is a major component of $\mathrm{Fe}$ (hydr)oxides, but is also a constituent of clay minerals. $\mathrm{Al}$ is often used as a proxy for the clay content in soils and sediments. Rodrigues et al. [70] found that the variation of the total $\mathrm{Al}$ in soil content in soil and sediments expresses the sorptive capacity of aluminosilicates and $\mathrm{Al}$ oxides at the surfaces and edges of clay minerals better than the actual variability of clay contents.

For most trace elements, the independent variables (total concentrations of trace metals, $\mathrm{Al}, \mathrm{Fe}, \mathrm{Ca}$, organic carbon $(\mathrm{OC})$, and/or $(\mathrm{pH})$ ) were significant in predicting the dependent variable (ammonium-EDTA or acetic acid extractable concentration) when the level of significance is below 0.05 . For almost all trace elements, the total content was the most important predicting variable. For the ammonium-EDTA extractable content of $\mathrm{Zn}, \mathrm{Ni}, \mathrm{Cd}$, and $\mathrm{Pb}$, the organic carbon content was also an important predicting variable, which can be related to the fact that EDTA is able to form organometal complexes, which compete with organic matter in soil. The predictive value of total $\mathrm{Al}$ and $\mathrm{Fe}$ concentrations differed among different trace elements.

For $\mathrm{Zn}, \mathrm{Ni}$, As, and $\mathrm{Cd}$, the total $\mathrm{Ca}$ content was an explaining variable for their acid extractable content, besides the total content of these elements, whereas the predictive value of $\mathrm{Fe}$ and $\mathrm{Al}$ was less important.

In the present study, the "EDTA extractable pool" of $\mathrm{Cu}$ was not significantly affected by the major elements and organic carbon content of the sediments since the EDTA extractable fraction of this element was found to be proportional to its total content (Table 8). For the amount of $\mathrm{Cu}$ extracted with acetic acid, $\mathrm{pH}$ was also a significant explaining variable, together with the total $\mathrm{Cu}$ content of the sediments.
A linear correlation between EDTA extractable and total concentrations of $\mathrm{Cd}, \mathrm{Zn}, \mathrm{Cu}$, and $\mathrm{Pb}$ has been mentioned in several other studies [71, 72]. McGrath [73] mentioned that the amount of $\mathrm{Cd}, \mathrm{Cu}$, and $\mathrm{Ni}$ extracted by EDTA from 7 polluted and unpolluted Irish soils was related to total metal content, while the EDTA extractable $\mathrm{Zn}$ content was related to organic carbon. Filipek and Pawlowski [74] also mentioned a positive relationship between EDTA extractable $\mathrm{Cu}$ and organic carbon in soils, a relationship not observed in our dataset.

\subsection{Potential Use and Interpretation of the Results of Ammonium-EDTA and Acid Extractable Metal Concentrations}

3.5.1. Quantification of Metal Partitioning in Soils. Metal partitioning in soils can be quantified by models in which metal concentrations in the pore water are described as a function of the metal binding solid phases such as $\mathrm{Fe}$ and $\mathrm{Al}$ (hydr)oxides, organic matter, and clay and as a function of soil characteristics that influence trace element partitioning, such as $\mathrm{pH}$. The ratio between total metal content bound to a soil relative to its concentration in the soil solution is often represented by $\mathrm{Kd}$ coefficients. However, such a model assumes that the sorption capacity of a material is independent of the soil properties (organic matter content, $\mathrm{pH}$, clay content, etc.) and, therefore, single $\mathrm{Kd}$ values are not appropriate to predict metal solubility in soil. In the literature, several models can be found, in which it is assumed that exchangeable metals and protons compete for adsorption on soil exchange sites [75]. In these models, besides soil properties - such as $\mathrm{pH}$, organic carbon content, and CEC-total elements concentrations are often used to predict dissolved elements concentrations (i.e., elements concentrations in the pore water). However, several authors $[76,77]$ used extractions with $\mathrm{HNO}_{3}(0.43 \mathrm{~mol} / \mathrm{L}), \mathrm{HCl}$, or EDTA to estimate the available pool of an element for use in solid-solution partitioning modeling, instead of using total metal concentrations.

In a study of Cappuyns et al. [78], ammonium-EDTA extractable metal concentrations were used instead of total metal concentrations. Stepwise multiple linear regression was performed with $\mathrm{pH}\left(\mathrm{CaCl}_{2}\right)$, organic carbon content, clay content, $\mathrm{CaCl}_{2}$ extractable element concentrations, dissolved organic carbon (DOC) content in de $\mathrm{CaCl}_{2}$ extracts, and ammonium-EDTA extractable element concentrations. With this model, in which the EDTA extractable element fraction represented the "available" pool of the element, Cd and $\mathrm{Zn}$ concentrations in the pore water could be predicted very well, based on $\mathrm{pH}$, organic carbon content, and EDTA extractable $\mathrm{Zn}$ and Cd concentrations. Rodrigues et al. [79] derived Freundlich-type models based on commonly available soil properties ( $\mathrm{pH}$, organic carbon, and clay) as well as extended models that used other properties such as amorphous $\mathrm{Al}$ and Fe oxides and evaluated their possible use in risk assessment. The approach enabled the prediction of the reactivity of potentially toxic elements.

Empirical partition relations can be useful to describe metal partitioning in soils, especially in large-scale 
TABLE 8: Ammonium-EDTA and acetic acid extractable element concentrations as a function of their total concentrations and total concentrations of $\mathrm{Al}, \mathrm{Fe}, \mathrm{Ca}$, and organic carbon $(\mathrm{OC}) .(n=72$, *significant at $\alpha=0.05)$. Acetic acid is abbreviated as "HOAc" in the equations.

\begin{tabular}{|c|c|}
\hline Acetic acid & $r^{2}$ \\
\hline $\log [\mathrm{Cu}]_{\mathrm{HOAC}}=1.073 \log [\mathrm{Cu}]_{\text {total }}+0.363 \mathrm{pH}-3.645$ & $0.851^{*}$ \\
\hline $\log [\mathrm{Cr}]_{\mathrm{HOAc}}=0.958 \log [\mathrm{Cr}]_{\text {total }}-0.408 \log [\mathrm{Fe}]_{\text {total }}-1.683$ & 0.345 \\
\hline $\log [\mathrm{Zn}]_{\mathrm{HOAc}}=1.013 \log [\mathrm{Zn}]_{\text {total }}+0.479 \log [\mathrm{Ca}]_{\text {total }}-0.399 \log [\mathrm{Al}]_{\text {total }}-0.312$ & $0.856^{*}$ \\
\hline $\log [\mathrm{Ni}]_{\mathrm{HOAc}}=0.915 \log [\mathrm{Ni}]_{\text {total }}+0.557 \log [\mathrm{Ca}]_{\text {total }}-0.439 \log [\mathrm{Al}]_{\text {total }}-0.478$ & $0.766^{*}$ \\
\hline $\log [\mathrm{As}]_{\mathrm{HOAc}}=1.356 \log [\mathrm{Ca}]_{\text {total }}+0.649 \log [\mathrm{As}]_{\text {total }}-0.617 \log [\mathrm{Fe}]_{\text {total }}+0.641 \log [\mathrm{Al}]_{\text {total }}-1.101$ & $0.751^{*}$ \\
\hline $\log [\mathrm{Cd}]_{\mathrm{HOAc}}=0.663 \log [\mathrm{Cd}]_{\mathrm{total}}+0.268 \log [\mathrm{Ca}]_{\mathrm{total}}-0.077$ & $0.835^{*}$ \\
\hline $\log [\mathrm{Pb}]_{\text {HOAc }}=-2.93 \mathrm{pH}+0.75 \log [\mathrm{Pb}]_{\text {total }}-0.905 \log [\mathrm{Fe}]_{\text {total }}+1.071 \log [\mathrm{Al}]_{\text {total }}-0.598 \log [\mathrm{OC}]-1.289$ & $0.968^{*}$ \\
\hline $\log [\mathrm{Co}]_{\mathrm{HOAc}}=0.591 \log [\mathrm{Co}]_{\mathrm{total}}+0.457 \log [\mathrm{Ca}]-0.591$ & $0.590^{*}$ \\
\hline \multicolumn{2}{|l|}{ Ammonium-EDTA } \\
\hline $\log [\mathrm{Cu}]_{\mathrm{EDTA}}=1.058 \log [\mathrm{Cu}]_{\text {total }}-0.546$ & $0.698^{*}$ \\
\hline $\log [\mathrm{Cr}]_{\mathrm{EDTA}}=0.512 \log [\mathrm{Cr}]_{\text {total }}+0.159 \mathrm{pH}-0.063$ & 0.393 \\
\hline $\log [\mathrm{Zn}]_{\mathrm{EDTA}}=1.043 \log [\mathrm{Zn}]_{\text {total }}+0.368 \log [\mathrm{OC}]+0.268 \log [\mathrm{Ca}]_{\text {total }}-0.765$ & $0.883^{*}$ \\
\hline $\log [\mathrm{Ni}]_{\mathrm{EDTA}}=0.858 \log [\mathrm{Ni}]_{\text {total }} \pm 0.172 \mathrm{pH}+0.326 \log [\mathrm{OC}]+0.473$ & $0.715^{*}$ \\
\hline $\log [\mathrm{As}]_{\mathrm{EDTA}}=0.878 \log [\mathrm{As}]_{\text {total }}+0.513 \log [\mathrm{Al}]_{\text {total }}-0.748 \log [\mathrm{Fe}]_{\text {total }}+0.373 \log [\mathrm{Ca}]_{\text {total }}-1.616$ & $0.670^{*}$ \\
\hline $\log [\mathrm{Cd}]_{\mathrm{EDTA}}=0.663 \log [\mathrm{Cd}]_{\text {total }}+0.345 \log [\mathrm{OC}]+0.220 \log [\mathrm{Fe}]_{\text {total }}-0.62$ & $0.883^{*}$ \\
\hline $\log [\mathrm{Pb}]_{\mathrm{EDTA}}=1.017 \log [\mathrm{Pb}]_{\text {total }}-0.338 \log [\mathrm{Al}]_{\text {total }}+0.166 \log [\mathrm{Fe}]_{\text {total }}+0.183 \log [\mathrm{OC}]+0.085 \mathrm{pH}-1.289$ & $0.749^{*}$ \\
\hline $\log [\mathrm{Co}]_{\mathrm{EDTA}}=-0.384 \log [\mathrm{OC}]+0.333 \log [\mathrm{Co}]_{\mathrm{total}}+3.75$ & 0.192 \\
\hline
\end{tabular}

applications, and offer the advantage that they are simple to understand and can be used by nonexpert users [80].

\subsubsection{Relation between EDTA Extractable Metal Concentra-} tions and Plant Uptake? For trace elements, total concentrations in soil are mostly used as an input in risk assessment models. However, trace elements in contaminated soil are rarely released completely as only a portion of trace elements is "bioavailable" or "geoavailable" (which means that the elements can be released and become available for biological uptake). Several authors claim that extractions such as extractions with EDTA and acetic acid can be used to evaluate the bioavailable fraction of an element in soil. However, the interpretation of the term "bioavailability" can vary widely as the availability and uptake of elements will also depend of the type of organism (plant, earthworm). EDTA salts have mainly been used to assess the availability of metals to plants, since they are believed to mimic rhizosphere effects in the soil. For example, a study of Bakircioglu et al. [81] indicated the extractable $\mathrm{Pb}$ and $\mathrm{Ni}$ of soils by EDTA single extraction procedures were significantly correlated with the metal contents of wheat grains. According to Anyanwu et al. [82], EDTA can be used to quantify the empirical relationships between plant uptake and soil metal contents. In another study, a significant positive correlation was found between EDTA extractable metals and metal accumulation in the shoot of Brassica juncea L. [83]. However, other studies (e.g., [84]) showed that extracting agents such as EDTA can not be used as universal soil extraction for estimating $\mathrm{Cu}, \mathrm{Zn}$, and Ni uptake by barley.

Peijnenburg et al. [85] made an overview of empirical methods for extraction of metals from soils as a surrogate for bioavailable and bioaccessible metal pools. They concluded that the value of these chemical methods for measuring bioavailability can be significantly improved when the species, metal, and soil specific aspects of bioavailability are more accurately taken into account.

3.5.3. Estimation of "Available Element Fraction" for Use in Risk Assessment and LCA. In the case of remediation projects for soils and sediments, trace element "availability" is also an important consideration since only a portion of the total metal load in soils or sediments can be considered as "geoavailable" or mobile. In a risk-conservative approach, it is assumed that all the metals contained in a solid matrix (soil, sediment, waste material, etc.) will be released. When this "total metal content" is used as an input in life cycle analysis ( $L C A)$, this will most likely result in an overestimation of the risk associated with the trace elements. Additionally, LCA typically covers an extended period of time (depending on the life cycle of a product or process), so long-term trace element emissions have to be assessed. The assessment of trace element released from soils and sediments on the long term is still controversial. Several methods and procedures have been proposed to estimate the long-term emissions of trace elements contained in soils, sediments, and waste materials, but there is no consensus as to which method performs best [86]. Extractions with "mild" reagents such as ammonium-EDTA and acetic acid can be useful to estimate "geoavailable" element concentrations in soils and sediments, and they have the advantage that they are relatively easy to perform.

\section{Conclusion}

The present study shows that both ammonium-EDTA and acetic acid have a different capacity to extract elements, 
depending on the elements and on the characteristics of the matrix that is being extracted (sediments in this case). The estimation of the potential (long-term) trace element availability is operationally defined by the extracting agents used. Making the comparison of "potential availability" by different single extractions (acetic acid or ammoniumEDTA extractions as defined by the SMT program) is not completely straightforward since operational conditions (L-S ratio, extraction time, etc.) and reagents are different.

For most trace elements $(\mathrm{Cu}, \mathrm{Zn}, \mathrm{Cd}, \mathrm{Ni}, \mathrm{As}$, and $\mathrm{Pb})$, a significant linear relationship could be established between their ammonium-EDTA or acetic acid extractable concentrations and their total concentrations, organic carbon content $\mathrm{pH}$, and $\mathrm{Fe}, \mathrm{Al}$, and/or Ca content. The scientific understanding of trace element partitioning in the complex soil-water system with these simple models is rather limited, but they offer the opportunity to use data from single extractions in a more comprehensive way.

Although single extractions with extracting agentssuch as ammonium-EDTA and acetic acid that aim to extract the "mobilizable" pool of elements from soils and sediments - can be statistically related to soil properties, they are primarily determined by the total element content in the soil or sediments. Despite the fact that single extractions with ammonium-EDTA and acetic acid cannot directly be related to the bioavailability of elements, they can provide input data for use in risk assessment models. Additionally, they also offer possibilities to perform a fast screening of the mobilizable pool of elements in soils and sediments.

\section{Acknowledgments}

Grateful acknowledgements are made to Talia Stough for the improvement of the English language of the paper and to the anonymous reviewers for their constructive comments on the first version of the paper.

\section{References}

[1] J. H. Duffus, "Heavy metals—a meaningless term?" Pure and Applied Chemistry, vol. 74, no. 5, pp. 793-807, 2002.

[2] M. E. Hodson, "Heavy metals-geochemical bogey men?" Environmental Pollution, vol. 129, no. 3, pp. 341-343, 2004.

[3] P. M. Driessen and R. Dudal, The Major Soils of the World, Lecture Notes on Their Geography, Formation, Proiperties and Use, Agricultural University of Wageningen and Katholieke Universiteit Leuven, 1991.

[4] OVAM, Openbare Vlaamse Afvalstoffenmaatschappij. Ontwerp uitvoeringsplan bagger- en ruimingspecie, OVAM, Mechelen, Belgium, 2007.

[5] IUSS Working Group WRB, "World reference base for soil resources A framework for international classification, correlation and communication," World Soil Resources Reports 103, FAO, Rome, Italy, 2006.

[6] A. C. Scheinost, R. Kretzschmar, S. Pfister, and D. R. Roberts, "Combining selective sequential extractions, X-ray absorption spectroscopy, and principal component analysis for quantitative zinc speciation in soil," Environmental Science and Technology, vol. 36, no. 23, pp. 5021-5028, 2002.

[7] W. J. G. M. Peijnenburg, M. Zablotskaja, and M. G. Vijver, "Monitoring metals in terrestrial environments within a bioavailability framework and a focus on soil extraction," Ecotoxicology and Environmental Safety, vol. 67, no. 2, pp. 163179, 2007.

[8] A. L. Nolan, M. J. McLaughlin, and S. D. Mason, "Chemical speciation of $\mathrm{Zn}, \mathrm{Cd}, \mathrm{Cu}$, and $\mathrm{Pb}$ in pore waters of agricultural and contaminated soils using donnan dialysis," Environmental Science and Technology, vol. 37, no. 1, pp. 90-98, 2003.

[9] J. L. Roulier, S. Belaud, and M. Coquery, "Comparison of dynamic mobilization of $\mathrm{Co}, \mathrm{Cd}$ and $\mathrm{Pb}$ in sediments using DGT and metal mobility assessed by sequential extraction," Chemosphere, vol. 79, no. 8, pp. 839-843, 2010.

[10] M. Koster, L. Reijnders, N. R. Van Oost, and W. J. G. M. Peijnenburg, "Comparison of the method of diffusive gels in thin films with conventional extraction techniques for evaluating zinc accumulation in plants and isopods," Environmental Pollution, vol. 133, no. 1, pp. 103-116, 2005.

[11] H. Vandenhove, K. Antunes, J. Wannijn, L. Duquène, and M. Van Hees, "Method of diffusive gradients in thin films (DGT) compared with other soil testing methods to predict uranium phytoavailability," Science of the Total Environment, vol. 373, no. 2-3, pp. 542-555, 2007.

[12] O. Mojsilovic, R. G. McLaren, and L. M. Condron, "Modelling arsenic toxicity in wheat: simultaneous application of diffusive gradients in thin films to arsenic and phosphorus in soil," Environmental Pollution, vol. 159, no. 10, pp. 2996-3002, 2011.

[13] P. M. V. Nirel and F. M. M. Morel, "Pitfalls of sequential extractions," Water Research, vol. 24, no. 8, pp. 1055-1056, 1990.

[14] I. Maiz, M. V. Esnaola, and E. Millán, "Evaluation of heavy metal availability in contaminated soils by a short sequential extraction procedure," Science of the Total Environment, vol. 206, no. 2-3, pp. 107-115, 1997.

[15] J. L. Gómez Ariza, I. Giráldez, D. Sánchez-Rodas, and E. Morales, "Comparison of the feasibility of three extraction procedures for trace metal partitioning in sediments from south-west Spain," Science of the Total Environment, vol. 246, no. 2-3, pp. 271-283, 2000.

[16] P. S. Rendell, G. E. Batley, and A. J. Cameron, "Adsorption as a control of metal concentrations in sediment extracts," Environmental Science and Technology, vol. 14, no. 3, pp. 314$318,1980$.

[17] J. L. Howard and W. J. Vandenbrink, "Sequential extraction analysis of heavy metals in sediments of variable composition using nitrilotriacetic acid to counteract resorption," Environmental Pollution, vol. 106, no. 3, pp. 285-292, 1999.

[18] A. Tessier and P. G. C. Campbell, "Comments on the testing of the accuracy of an extraction procedure for determining the partitioning of trace metals in sediments," Analytical Chemistry, vol. 60, no. 14, pp. 1475-1476, 1988.

[19] A. Tessier and P. G. C. Campbell, "Comment on 'Pitfalls of sequential extractions' by P.M.V. Nirel and F.M.M. Morel," Water Research, vol. 24, pp. 1055-1056, 1991.

[20] E. Tipping, N. B. Hetherington, J. Hilton, D. W. Thompson, E. Bowles, and J. Hamilton-Taylor, "Arrtifacts in the use of chemical extraction to determine distributions of metals between oxides of manganese and iron," Analytical Chemistry, vol. 57, pp. 1944-1946, 1985.

[21] K. A. Gruebel, J. A. Davis, and J. O. Leckie, "The feasibility of using sequential extraction techniques for arsenic and 
selenium in soils and sediments," Soil Science Society of America Journal, vol. 52, no. 2, pp. 390-397, 1988.

[22] R. T. Dhoum and G. J. Evans, "Evaluation of uranium and arsenic retention by soil from a low level radioactive waste management site using sequential extraction," Applied Geochemistry, vol. 13, no. 4, pp. 415-420, 1998.

[23] M. J. La Force and S. Fendorf, "Solid-phase iron characterization during common selective sequential extractions," Soil Science Society of America Journal, vol. 64, no. 5, pp. 1608$1615,2000$.

[24] X.-Q. Shan and B. Chen, "Evaluation of sequential extraction for speciation of trace metals in model soil containing natural minerals and humic acid," Analytical Chemistry, vol. 65, no. 6, pp. 802-807, 1993.

[25] J. L. Gómez Ariza, I. Giráldez, D. Sánchez-Rodas, and E. Morales, "Selectivity assessment of a sequential extraction procedure for metal mobility characterization using model phases," Talanta, vol. 52, no. 3, pp. 545-554, 2000.

[26] S. Van Herreweghe, R. Swennen, C. Vandecasteele, and V. Cappuyns, "Solid phase speciation of arsenic by sequential extraction in standard reference materials and industrially contaminated soil samples," Environmental Pollution, vol. 122, no. 3, pp. 323-342, 2003.

[27] P. Quevauviller, “Operationally defined extraction procedures for soil and sediment analysis I. Standardization," Trends in Analytical Chemistry, vol. 17, no. 5, pp. 289-298, 1998.

[28] A. Ure, P. Quevauviller, H. Munteau, and B. Griepink, "Improvements in the determination of extractable contents of trace metals in soils and sediments prior to certification," Tech. Rep., Community Bureau of reference, Commission of the European Communities, 1993.

[29] G. Rauret, J. F. López-Sánchez, A. Sahuquillo et al., "Improvement of the BCR three step sequential extraction procedure prior to the certification of new sediment and soil reference materials," Journal of Environmental Monitoring, vol. 1, no. 1, pp. 57-61, 1999.

[30] A. Sahuquillo, J. F. López-Sánchez, R. Rubio et al., "Use of a certified reference material for extractable trace metals to assess sources of uncertainty in the BCR three-stage sequential extraction procedure," Analytica Chimica Acta, vol. 382, no. 3, pp. 317-327, 1999.

[31] S. K. Gupta, M. K. Vollmer, and R. Krebs, "The importance of mobile, mobilisable and pseudo total heavy metal fractions in soil for three-level risk assessment and risk management," Science of the Total Environment, vol. 178, pp. 11-20, 1996.

[32] W. P. Miller, D. C. Martens, L. W. Zelazny, and E. T. Kornegay, "Forms of solid phase copper in copper-enriched swine manure," Journal of Environmental Quality, vol. 15, no. 1, pp. 69-72, 1986.

[33] O. K. Borggaard, "Selective extraction of amorphous iron oxides by EDTA from a Danish sandy loam," Journal of Soil Science, vol. 30, pp. 727-734, 1979.

[34] B. Nowack and L. Sigg, "Dissolution of Fe(III)(hydr) oxides by metal-EDTA complexes," Geochimica et Cosmochimica Acta, vol. 61, no. 5, pp. 951-963, 1997.

[35] M. A. M. Kedziorek and A. C. M. Bourg, "Solubilization of lead and cadmium during the percolation of EDTA through a soil polluted by smelting activities," Journal of Contaminant Hydrology, vol. 40, no. 4, pp. 381-392, 2000.

[36] L. Madrid and E. Díaz-Barrientos, "Release of metals from homogeneous soil columns by wastewater from an agricultural industry," Environmental Pollution, vol. 101, no. 1, pp. 43-48, 1998.
[37] B. Sun, F. J. Zhao, E. Lombi, and S. P. McGrath, "Leaching of heavy metals from contaminated soils using EDTA," Environmental Pollution, vol. 113, no. 2, pp. 111-120, 2001.

[38] Z. Zou, R. Qiu, W. Zhang et al., "The study of operating variables in soil washing with EDTA," Environmental Pollution, vol. 157, no. 1, pp. 229-236, 2009.

[39] N. Papassiopi, S. Tambouris, and A. Kontopoulos, "Removal of heavy metals from calcareous contaminated soils by EDTA leaching," Water, Air, and Soil Pollution, vol. 109, no. 1-4, pp. $1-15,1999$.

[40] N. Finžgar and D. Leštan, "Multi-step leaching of $\mathrm{Pb}$ and $\mathrm{Zn}$ contaminated soils with EDTA," Chemosphere, vol. 66, no. 5, pp. 824-832, 2007.

[41] R. S. Tejowulan and W. H. Hendershot, "Removal of trace metals from contaminated soils using EDTA incorporating resin trapping techniques," Environmental Pollution, vol. 103, no. 1, pp. 135-142, 1998.

[42] P. Theodoratos, N. Papassiopi, T. Georgoudis, and A. Kontopoulos, "Selective removal of lead from calcareous polluted soils using the Ca-EDTA salt," Water, Air, and Soil Pollution, vol. 122, no. 3-4, pp. 351-368, 2000.

[43] A. Bermond and J. P. Ghestem, "Kinetic study of trace metal EDTA-desorption from contaminated soils," in Heavy Metals Release in Soils, H. M. Selim and D. L. Sparks, Eds., pp. 131147, Lewis, 2001.

[44] A. Bermond, "Limits of sequential extraction procedures reexamined with emphasis on the role of $\mathrm{H}^{+}$ion reactivity," Analytica Chimica Acta, vol. 445, no. 1, pp. 79-88, 2001.

[45] A. Polettini, R. Pomi, E. Rolle et al., "A kinetic study of chelantassisted remediation of contaminated dredged sediment," Journal of Hazardous Materials, vol. 137, no. 3, pp. 1458-1465, 2006.

[46] D. F. Kalf, M. A. G. T. Hoop van den, J. P. Rila, C. Posthuma, and T. P. Traas, "Environmental Risk Limits for Ethylene Diamine Tetra Acetic acid (EDTA). Rijksinstituut voor Volksgezondheid en Milieu RIVM (Ed.)," RIVM Report 601501010/2003, Bilthoven, The Netherlands, 2003.

[47] D. Jiraroj, F. Unob, and A. Hagège, "Degradation of Pb-EDTA complex by a $\mathrm{H}_{2} \mathrm{O}_{2} / \mathrm{UV}$ process," Water Research, vol. 40, no. 1, pp. 107-112, 2006.

[48] M. Pociecha and D. Lestan, "EDTA leaching of Cu contaminated soil using electrochemical treatment of the washing solution," Journal of Hazardous Materials, vol. 165, no. 1-3, pp. 533-539, 2009.

[49] A. Tessier, P. G. C. Campbell, and M. Blsson, "Sequential extraction procedure for the speciation of particulate trace metals," Analytical Chemistry, vol. 51, no. 7, pp. 844-851, 1979.

[50] A. M. Ure, "Single extraction schemes for soil analysis and related applications," Science of the Total Environment, vol. 178, pp. 3-10, 1996.

[51] H. A. van der Sloot, R. N. J. Comans, and O. Hjelmar, "Similarities in the leaching behaviour of trace contaminants from waste, stabilized waste, construction materials and soils," Science of the Total Environment, vol. 178, pp. 111-126, 1996.

[52] D. W. Nelson and L. E. Sommers, "Total carbon, organic carbon and organic matter," in Methods of Soil Analysis, part 2: Chemical and Biological Properties, pp. 516-593, 2nd edition, 198.

[53] R. Chhabra, J. Pleysier, and A. Cremers, "The measurement of the cation exchange capacity and exchangeable cations in soils: a new method," in Proceedings of the International Clay Conference, S. W. Bailey, Ed., pp. 439-449, Applied Publishing Ltd, Wilmette, Ill, USA, 1975. 
[54] L. P. van Reeuwijk, Procedures for Soil Analysis, ISRIC, Wageningen, The Netherlands, 3rd edition, 1992.

[55] C. A. Brockhoff, J. T. Creed, T. D. Martin, E. R. Martin, and S. E. Long, "EPA Method 200.8, Revision 5.5: determination of trace metals in waters and wastes by inductively coupled plasma-mass spectrometry," EPA-821R-99-017, p. 61 , October 1999.

[56] R. Webster, "Regression and functional relations," European Journal of Soil Science, vol. 48, no. 3, pp. 557-566, 1997.

[57] R. Webster, "Statistics to support soil research and their presentation," European Journal of Soil Science, vol. 52, no. 2, pp. 331-340, 2001.

[58] P. Quevauviller, E. A. Maier, B. Griepink, U. Fortunati, K. Vercoutere, and H. Muntau, "Certified reference materials of soils and sewage sludges for the quality control of trade element environmental monitoring," Trends in Analytical Chemistry, vol. 15, no. 10, pp. 504-513, 1996.

[59] M. Pueyo, G. Rauret, D. Lück et al., "Certification of the extractable contents of $\mathrm{Cd}, \mathrm{Cr}, \mathrm{Cu}, \mathrm{Ni}, \mathrm{Pb}$ and $\mathrm{Zn}$ in a freshwater sediment following a collaboratively tested and optimised three-step sequential extraction procedure," Journal of Environmental Monitoring, vol. 3, no. 2, pp. 243-250, 2001.

[60] P. Quevauviller, G. Rauret, A. Ure, J. Bacon, and H. Muntau, "The certification of the EDTA and acetic acid-extractable contents (mass fractions) of $\mathrm{Cd}, \mathrm{Cr}, \mathrm{Cu}, \mathrm{Pb}$ and $\mathrm{Zn}$ in sewage sludge amended soils CRMs 484 and 484," European Commision, BCR information, Reference materials. EUR 17127 EN, p. 99, 1997.

[61] A. E. Martell and R. M. Smith, Critical Stability Constants. Other Organic Ligands, vol. 3, Plenum Press, New York, NY, USA, 1977.

[62] A. E. Martell and R. M. Smith, Critical Stability Constants. First Supplement, vol. 5, Plenum Press, New York, NY, USA, 1982.

[63] W. A. Norvell, "Reactions of metal chelates in soil and nutrient solutions," in Microelements in Agriculture, J. J. Mortvedt, F. R. Cox, L. M. Shuman, and R. M. Welch, Eds., pp. 187-227, Soil Science Society of America, Madison, Wis, USA, 2nd edition, 1991.

[64] T. E. Furia, "Chapter 6-sequestrants in foods," in CRC Handbook of Food Additives, pp. 271-294, CRC Press, West Palm Beach, Fla, USA, 2nd edition, 1972.

[65] J. W. Buthing and K. M. Thong, "Stability constants for some 1 : 1 metal-carboxylate complexes," Canadian Journal of Chemistry, vol. 48, pp. 1654-1656, 1970.

[66] C. Kim, Y. Lee, and S. K. Ong, "Factors affecting EDTA extraction of lead from lead-contaminated soils," Chemosphere, vol. 51, no. 9, pp. 845-853, 2003.

[67] W. W. Wenzel, N. Kirchbaumer, T. Prohaska, G. Stingeder, E. Lombi, and D. C. Adriano, "Arsenic fractionation in soils using an improved sequential extraction procedure," Analytica Chimica Acta, vol. 436, no. 2, pp. 309-323, 2001.

[68] S. Tokunaga and T. Hakuta, "Acid washing and stabilization of an artificial arsenic-contaminated soil," Chemosphere, vol. 46, no. 1, pp. 31-38, 2002.

[69] V. Cappuyns, Heavy metal behaviour in overbank sediments and associated soils, Ph.D. thesis, Katholieke Universiteit Leuven, 2004.

[70] S. M. Rodrigues, B. Henriques, E. F. da Silva et al., "Evaluation of an approach for the characterization of reactive and available pools of 20 potentially toxic elements in soils: part II-Solid-solution partition relationships and ion activity in soil solutions," Chemosphere, vol. 81, no. 11, pp. 1560-1570, 2010.
[71] S. P. Singh, F. M. G. Tack, and M. G. Verloo, "Solidphase distribution of heavy metals as affected by single reagent extraction in dredged sediment derived surface soils," Chemical Speciation and Bioavailability, vol. 8, no. 1-2, pp. 3743, 1996

[72] G. Du Laing, N. Bogaert, F. M. G. Tack, M. G. Verloo, and F. Hendrickx, "Heavy metal contents $(\mathrm{Cd}, \mathrm{Cu}, \mathrm{Zn})$ in spiders (Pirata piraticus) living in intertidal sediments of the river Scheldt estuary (Belgium) as affected by substrate characteristics," Science of the Total Environment, vol. 289, no. 1-3, pp. 71-81, 2002.

[73] D. McGrath, "Application of single and sequential extraction procedures to polluted and unpolluted soils," Science of the Total Environment, vol. 178, pp. 37-44, 1996.

[74] T. Filipek and L. Pawlowski, "Total and extractable heavy metal content of some soils of the Lublin coal mining region," Science of the Total Environment, vol. 96, no. 1-2, pp. 131-137, 1990.

[75] S. Sauvé, W. Hendershot, and H. E. Allen, "Solid-solution partitioning of metals in contaminated soils: dependence on $\mathrm{pH}$, total metal burden, and organic matter," Environmental Science and Technology, vol. 34, no. 7, pp. 1125-1131, 2000.

[76] P. F. Römkens, H. Y. Guo, C. L. Chu, T. S. Liu, C. F. Chiang, and G. F. Koopmans, "Characterization of soil heavy metal pools in paddy fields in Taiwan: chemical extraction and solid-solution partitioning," Journal of Soils and Sediments, vol. 9, no. 3, pp. 216-228, 2009.

[77] T. J. Schröder, T. Hiemstra, J. P. M. Vink, and S. E. A. T. M. Van Der Zee, "Modeling of the solid-solution partitioning of heavy metals and arsenic in embanked flood plain soils of the rivers rhine and meuse," Environmental Science and Technology, vol. 39, no. 18, pp. 7176-7184, 2005.

[78] V. Cappuyns, R. Swennen, and J. Verhulst, "Assessment of heavy metal mobility in dredged sediments: porewater analysis, single and sequential extractions," Soil and Sediment Contamination, vol. 15, no. 2, pp. 169-186, 2006.

[79] S. M. Rodrigues, B. Henriques, E. F. da Silva, M. E. Pereira, A. C. Duarte, and P. F. A. M. Römkens, "Evaluation of an approach for the characterization of reactive and available pools of twenty potentially toxic elements in soils: part I-The role of key soil properties in the variation of contaminants' reactivity," Chemosphere, vol. 81, no. 11, pp. 1549-1559, 2010.

[80] J. E. Groenenberg, Evaluation of models for metal partitioning and speciation in soils and their use in risk assessment Thesis, Ph.D. thesis, Wageningen University, 2011.

[81] D. Bakircioglu, Y. Bakircioglu-Kurtulus, and H. Ibar, "Comparison of extraction procedures for assessing soil metal bioavailability of to wheat grains," Clean, vol. 39 , no. 8 , pp. 728-734, 2011.

[82] E. C. Anyanwu, K. Ijeoma, J. E. Ehiri, and M. A. Saleh, "Bioavailable" Lead Concentration in Vegetable Plants grown in Soil from a reclaimed industrial site: health implications," Internet Journal of Food Safety, vol. 6, pp. 31-34, 2005.

[83] A. K. Gupta and S. Sinha, "Assessment of single extraction methods for the prediction of bioavailability of metals to Brassica juncea L. Czern. (var. Vaibhav) grown on tannery waste contaminated soil," Journal of Hazardous Materials, vol. 149, no. 1, pp. 144-150, 2007.

[84] J. M. Soriano-Disla, I. Gómez, J. Navarro-Pedreño, and A. LagBrotons, "Evaluation of single chemical extractants for the prediction of heavy metal uptake by barley in soils amended with polluted sewage sludge," Plant and Soil, vol. 327, no. 1, pp. 303-314, 2010.

[85] W. J. G. M. Peijnenburg, M. Zablotskaja, and M. G. Vijver, "Monitoring metals in terrestrial environments within 
a bioavailability framework and a focus on soil extraction," Ecotoxicology and Environmental Safety, vol. 67, no. 2, pp. 163179, 2007.

[86] J. Pettersen and E. G. Hertwich, "Critical review: life-cycle inventory procedures for long-term release of metals," Environmental Science and Technology, vol. 42, no. 13, pp. 46394647, 2008. 

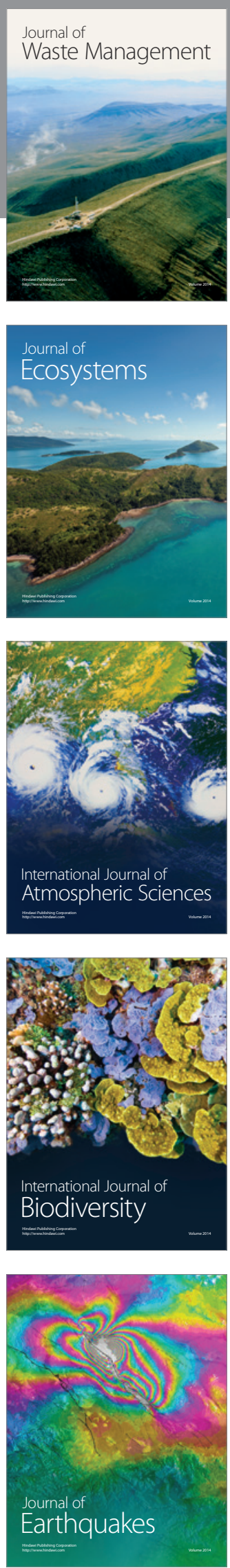
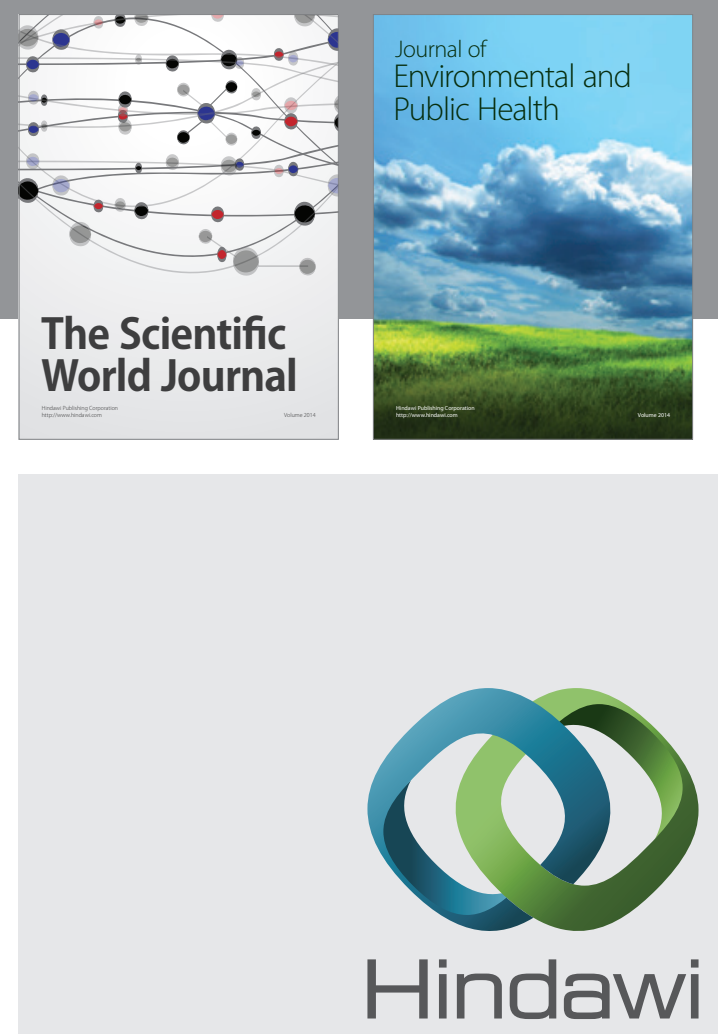

Submit your manuscripts at

http://www.hindawi.com
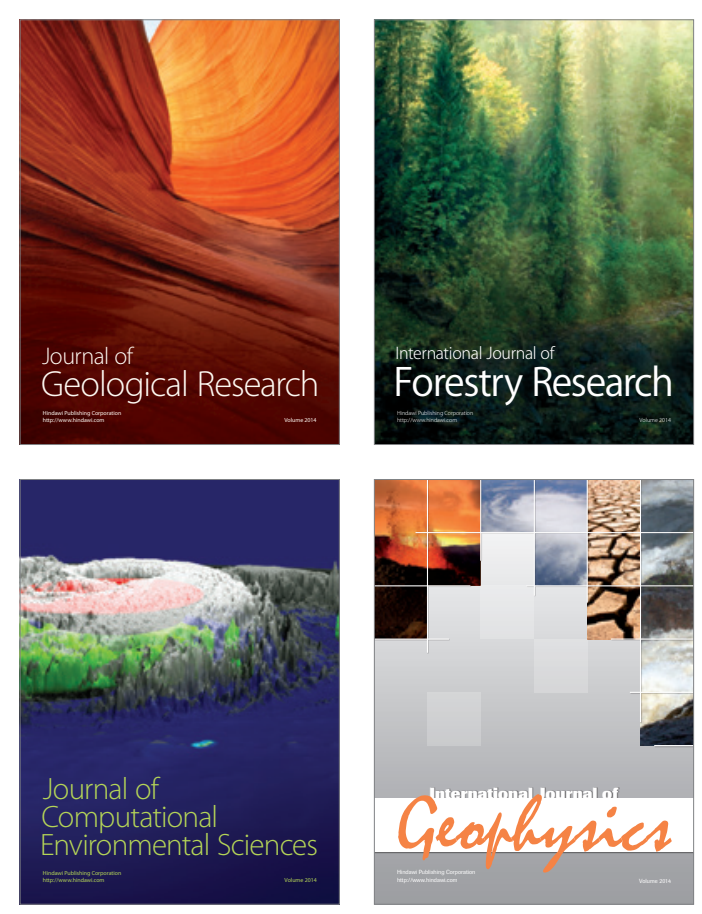
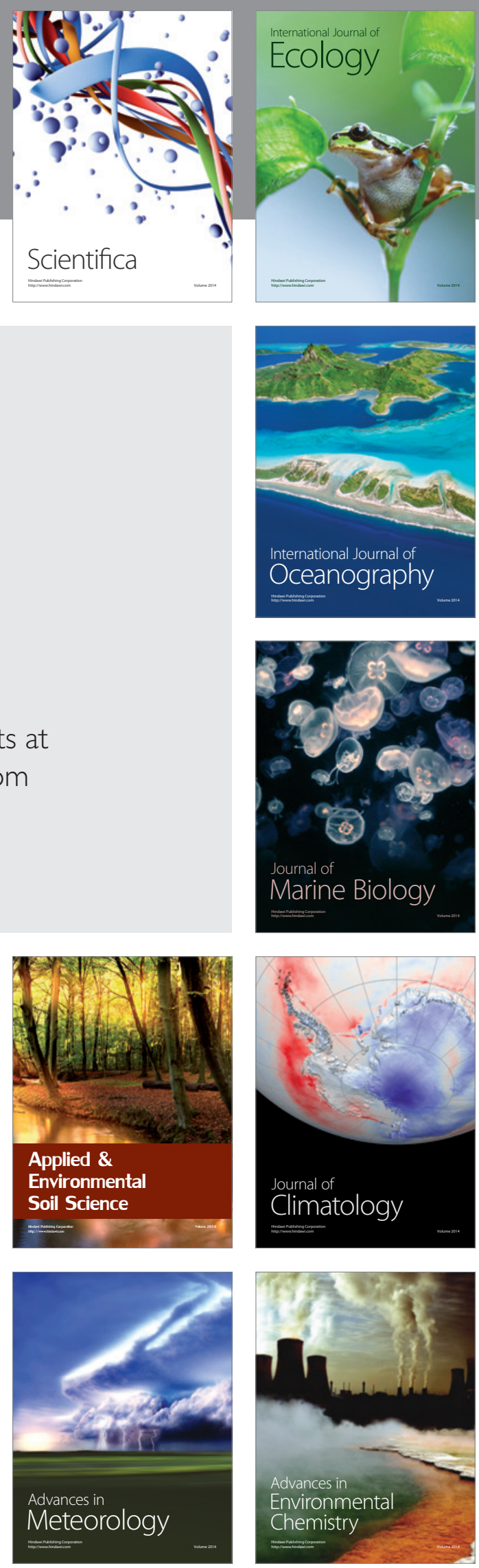